\title{
ANALISIS PERBANDINGAN KEKERASAN PERMUKAAN POROS AXLE SHAFT JENIS MATERIAL S-43 YANG DILAKUKAN DENGAN PROSES INDUKSI HARDENING PADA MESIN 12-9 B “KORA NETUREN”
}

\author{
Sumiyanto ${ }^{1}$ \\ Program Studi Teknik Mesin, Institut Sains dan Teknologi Nasional, Jakarta ${ }^{1}$ \\ email $^{1}$ : sumiyanto@istn.ac.id
}

\begin{abstract}
Hardening process is the process of hardening in a material heated above the critical temperature and then cooled quickly (quenched) to reach room temperature in order to improve hardness and strength of a material. Hardening process carried out on all the tools and some equipment or machine parts that have a major benefit is to obtain a higher hardness.

This research was conducted on 447 SNCM alloy steel which is a medium carbon steel grade that is equal to 0:30 to 0:38\%. This type of steel can be hardened by heat treatment process that is by heating the steel at a temperature of $500^{\circ} \mathrm{C}$, for 1 hour as the preheating temperature (preheated). Then proceed to the process of hardening, namely austenising temperature with $900^{\circ} \mathrm{C}$ with holding time 2 hours and cooled with oil and then water in tempering with holding time 1 hour at $300^{\circ} \mathrm{C}, 400^{\circ} \mathrm{C}$ and $500^{\circ} \mathrm{C}$.

From research result obtained using the Vickers hardness values that increase occurred in materials that undergo a process of hardening at $900^{\circ} \mathrm{C}$ cooling using water media, whereas the lowest hardness value occurs in the original material.
\end{abstract}

Keywords: Hardening, Holding Time, Heat Treatment Process.

\section{PENDAHULUAN}

\section{Latar Belakang Masalah.}

Dalam proses induksi hardening untuk mencari parameter penyetelan waktu penahanan quenching masih sering menggunakan perasaan atau uji coba. hal ini menimbulkan masalah karena. parameter tersebut belum terstandarkan dengan jelas.

Permasalahan utama yang sering terjadi saat proses induksi yaitu tidak tercapainya standar kedalaman penetrasi kekerasan permukaan efektif pada material poros axle shaft. Contoh kasus: saat penyetelan awal mesin, kedalaman penetrasi yang didapat aktual 2,5 mm sedangkan standar penetrasi adalah 3-6 mm, jadi hasil proses adalah NG. Begitu juga apabila, kedalaman penetrasi actual akan mencapai $8 \mathrm{~mm}$.

Oleh karena itu, dibutuhkan analisa yang lebih mendetail mengenai hubungan antara parameter proses specs material dan waktu quenching. Untuk pembahasan di penelitian ini penulis memberi batasan untuk analisis "hardening" atau pengerasan permukaan saat proses induksi hardening untuk material axle shaft dengan jenis s-43.

Pengerasan permukaan adalah sebuah metode yang digunakan untuk memperbaiki sifat material, namun hanya pada permukaannya saja. Jadi pada bagian dalam material tetap memiliki sifat yang sama seperti sebelumnmya.

Pada penelitian ini, penulis akan membahas proses induksi hardening.

Induksi hardening adalah pemanasan baja dengan cara mengalirkan arus listrik frekuensi tinggi. Metoda pemanasan induksi terdiri dari ketika benda kerja logam (dalam kasus ini adalah poros axle shaft) diletakkan pada suatu magnit tidak tetap divariasikan atau disebut juga eddy Current diinduksikan. Eddy Current yang dihasilkan diubah menjadi panas.

\section{Permasalahan}

Pokok masalah yang dijabarkan peneliti di latar belakang penelitian ini adalah diperlukannya suatu analisis perbandingan antara hasil kedalaman penetrasi kekerasan efektif material poros axle shaft terhadap parameter input mesin saat penyetelan awal pergantian model atau awal proses agar sesuai tuntutan standar penetrasi pada proses induction hardening untuk poros axle shaft material S43 di PT.X

\section{Tujuan}

Tujuan penelitian ini adalah untuk analisa proses hardening material poros axle shaft jenis 
s-43 saat proses induction hardening yang mencakup hasil kedalaman penetrasi kekerasan efektif pada material dan perbandingannya dengan input parameter yang digunakan. Agar sesuai dengan ketentuan proses, dan dapat digunakan saat penyetelan awal proses dan mencapai standar tuntutan kualitas yang diinginkan (quality check standard) pada mesin line axle shaft di PT.X.

\section{Metodologi Penelitian}

Metodologi penelitian yang digunakan dalam penyusunan laporan penelitian ini adalah sebagai berikut:

1. Melakukan identifikasi permasalahan yang ada.

2. Melakukan studi pustaka.

3. Menyiapkan data-data yang dibutuhkan.

4. Melakukan perhitungan sesuai dimensi axle shaft dan input parameter pada mesin.

5. Menarik kesimpulan dengan berdasarkan pada hasil perbandingan.

\section{TINJAUAN PUSTAKA \\ Poros Axle Shaft.}

Poros axle shaft S-43 adalah salah satu komponen kendaraan berbentuk poros putar yang berada di dalam rear axle (poros garden) mobil berpenggerak roda belakang dengan merk dagang $\mathrm{X}$ produksi tahun 2013. Axle shaft ini berfungsi untuk meneruskan distribusi tenaga putaran mesin ke putaran roda. Berikut adalah gambaran penggunaan komponen axle shaft pada mobil:

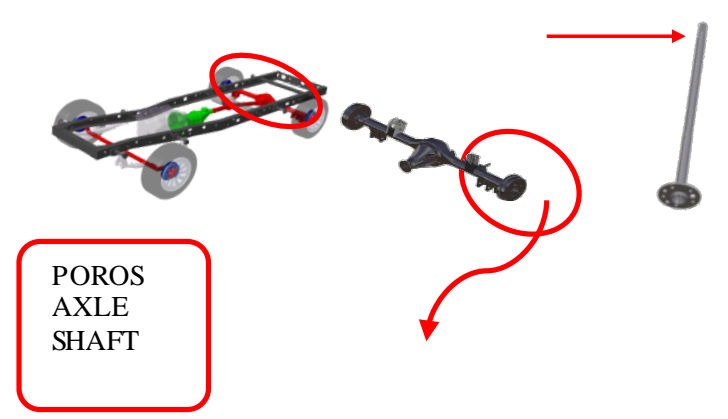

Gambar 1. Komponen Axle Shaft Pada Mobil

Sesuai dengan fungsinya, maka poros axle shaft harus memiliki kekuatan material sesuai tenaga dan torsi maksimum yang dihasilkan mesin mobil yang dipasang pada mobil Toyota New Avanza tahun 2013. Berikut adalah spesifikasi kapasitas mesin dan torsi maksimum yang dimiliki oleh mobil tersebut:
TABEL 1.SPEISFIKASI MOBIL TOYOTA AVANZA

\begin{tabular}{|c|c|c|c|c|}
\hline \multicolumn{3}{|l|}{ MESIN/ENGINE } & K3.VE & $352 \cdot V E$ \\
\hline \multicolumn{3}{|c|}{ Tipe Mesin / Engine Type } & \multicolumn{2}{|c|}{ IL, 4 CVlinder, $16 \mathrm{~V}$, DOHC, WTTi } \\
\hline \multicolumn{3}{|c|}{ Isis Silindet / Displacement } & 1,298 & 1,495 \\
\hline \multicolumn{3}{|c|}{ Daya Maksimum / Maximum Power } & $92 / 6,000$ & $104 / 6,000$ \\
\hline \multirow{2}{*}{\multicolumn{3}{|c|}{$\begin{array}{l}\text { Torsi Maksimum/Maximum Torque } \quad \mathrm{kgm} / \mathrm{rpm} \\
\text { Jenis/Type }\end{array}$}} & $11.9 / 4,400$ & $139 / 4,400$ \\
\hline & & & \multicolumn{2}{|c|}{ Bensin tanpa Timbal / Unleaded Gasoline } \\
\hline \multirow[t]{2}{*}{ Bahan Bakar/fuel } & \multicolumn{2}{|c|}{ Sistem/System } & \multicolumn{2}{|c|}{ Sistem Bahan Bakar Elektronik / Electronic Fuel Injection (EFi) } \\
\hline & \multicolumn{2}{|c|}{ 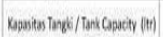 } & \multicolumn{2}{|c|}{45} \\
\hline
\end{tabular}

Berdasarkan tabel 1. di atas, untuk model New Avanza perhitungan kekuatan material mengikuti tipe mesin 35z-ve karena untuk kedua varian tipe mesin tersebut menggunakan dimensi dan jenis material poros axle shaft yang sama yaitu S-43.

Karena fungsinya yang sangat vital pada mobil, dan uraian gaya-gaya atau beban yang diterima poros axle shaft di mobil maka material poros axle shaft harus kuat, stabil, keras di area permukaan material, tetapi tetap lentur di area tengah intinya. Oleh karena itu untuk proses permesinan poros axle shaft harus di proses induksi hardening. Untuk material pada poros axle shaft ini adalah S-43 dan termasuk kategori baja karbon medium.

\section{Perhitungan Ke kuatan Material}

Pada benda pejal/padat, torsi adalah putaran dari sebuah benda dan menghasilkan momen, oleh karena itu, torsi terdiri dari unsur Newton meter atau satuan gaya. Arah kerjanya axis putar, resultan tegangan potong pada hal ini berbentuk radius. Pada poros seragam perhitungan torsi adalah:

$$
T=\frac{J_{T}}{r} \tau=\frac{J_{T}}{\ell} G \theta
$$

Keterangan:

- $T$ adalah tegangan maksimum pada permukaan luar

- $J_{t}$ adalah konstanta momen putar, hal ini mengidentifikasikan area kedua

- $J_{z z}$ adalah untuk pipa sesumbu, atau hanya putaran poros pejal. Untuk bentuk lainnya j harus dideterminasikan dengan yang lain.

- $R \quad$ adalah jarak antara sumbu putar dan titik terjauh di bagian permukaan

- $\quad \ell \quad$ adalah panjang momen benda yang terjadi atau lebih

- $\Theta \quad$ adalah sudut putar dalam radian

- $G$ adalah modulus geser atau lebih umum lagi disebut nilai modulus kekakuan dan biasanya dinotasikan dalam giga pascals (gpa), lbf/in ${ }^{2}$ (psi), or lbf/ft ${ }^{2}$

- Produk $j_{t}$ g dipanggil kekakuan torsional $w_{t}$ 
Tegangan potong pada inti sebuah poros adalah:

Berdasarkan rumus tegangan potong tertinggi terjadi pada permukaan luar poros, atau $=\frac{T r}{J_{T}}$ jarak radius maksimum. Tingginya $\tau_{\varphi_{z}}=\frac{T}{J_{T}} \quad$ tegangan pada permukaan dapat dipengaruhi oleh konsentrasi

tegangan seperti titik kekasaran permukaan. Oleh karena itu, poros dengan torsi tinggi diproses dengan tingkat

kekasaran permukaan yang halus atau dipolish untuk mengurangi tegangan maximum poros dan meningkatkan umur pakainya.

Sudut putar dapat dicari dengan rumus:

$$
\varphi=\frac{T \ell}{w_{T}} .
$$

Sedangkan kecepatan putar dapat dicari dengan rumus

$$
\omega=2 \pi f
$$

Dan torsi juga dipengaruhi oleh power:

$$
P=T \omega
$$

Rumus untuk mencari torsi maksimum:

$$
T_{\max }=\frac{\tau_{\max } J_{z z}}{r}
$$

Dengan pensubtitusian, titik polar inersia dapat dicari dengan rumus:

$$
d=\sqrt[3]{\frac{16 T_{\max }}{\pi \tau_{\max }}}
$$

\section{Baja Karbon dan Kandungannya}

Baja karbon adalah paduan besi karbon di mana unsur karbon sangat menentukan sifatsifatnya, sedang unsur-unsur paduan lainnya yang juga terkandung didalamnya terjadi karena proses pembuatannya. Sifat baja karbon ditentukan oleh persentase kandungan karbon pada mikrostrukturnya. Baja paduan adalah baja dengan kandungan sebuah unsur lain atau dengan kadar yang berlebih dari pada karbon biasanya dalam baja karbon. Menurut prosentase karbon baja dibagi menjadi 3 yaitu:

\section{Baja Karbon Rendah (Low Carbon Steel);}

Kandungan karbon kurang dari $0.25 \%$, yang mana sangat luas penggunaannya sebagai baja konstruksi, seperti baja profil rangka bangunan, baja tulangan beton, mur, baut, plat, dan pipa baja. Baja ini kekuatannya relatif rendah, lunak, tetapi keuletannya tinggi, mudah di bentuk dan diproses mesin.

\section{Baja Karbon Menengah (Medium Carbon}

\section{Steel);}

Kandungan karbonnya $0.25-0.55 \%$ lebih kuat dan keras, dan dapat dikeraskan. Penggunaannya hampir sama dengan baja karbon rendah, digunakan untuk yang memerlukan kekuatan dan ketangguhan yang lebih tinggi, dan banyak digunakan sebagai baja konstruksi, poros, roda gigi dan rantai.

3. Baja Karbon Tinggi (High Carbon Steel); Kandungan karbonnya 0.55-1.7\% lebih kuat dan lebih keras, tetapi keuletan dan ketangguhannya rendah. Baja ini banyak digunakan untuk alat-alat perkakas, yang biasanya memerlukan sifat tahan aus, misal; mata bor, remer, tap, dan perkakas tangan lainnya.

Sedangkan pengertian kode jenis material S-43 disini, S adalah untuk steel atau baja karbon. 43 adalah prosentase kandungan karbon, $43 \times 100 \%=$ $0,43 \%$. Kandungan $0,43 \%$ karbon pada baja mengidentifikasikan baja tersebut termasuk kategori baja karbon menengah (medium carbon steel).

Menurut kadar unsur paduan, baja paduan dapat dibagi ke dalam dua golongan yaitu baja paduan rendah dan baja paduan tinggi. Baja paduan rendah unsur paduannya dibawah $10 \%$, sedangkan baja paduan tinggi adalah baja dengan kandungan paduan di atas 10\%. Dan untuk baja khusus mempunyai unsur-unsur paduan yang tinggi karena pemakaianpemakaian yang khusus. Baja khusus seperti baja tahan karat, baja tahan panas, baja perkakas, baja listrik. Unsur utama dari baja tahan karat adalah chrom yang juga merupakan sebagai unsur terpenting untuk memperoleh sifat baja tahan terhadap korosi.

Baja tahan karat ada tiga macam menurut strukturnya yaitu baja tahan karat feritis, baja tahan karat martensitas dan austenitis. Baja tahan panas, tahan juga terhadap korosi. Baja ini tahan korosi pada suhu lingkungan lebih tinggi atau oksidasi. Sedangkan baja perkakas adalah baja yang dibuat tidak berukuran besar tetapi memegang peranan dalam industri. Unsur-unsur paduan dalam karbitnya diperlukan untuk memperoleh sifat-sifat tersebut dan kuat pada temperatur tinggi. Baja listrik banyak dipakai dalam bidang elektronika.

\section{Pengaruh Unsur Paduan Baja}

Sifat baja sangat tergantung pada unsur paduan yang terkandung. Unsur paduan ditambahkan untuk mengurangi sifat yang tidak diinginkan pada baja karbon dan memperbaiki atau menambah sifat-sifat lain yang dikehendaki pada logam baja. Pengaruh dari beberapa unsur paduan baja dijelaskan di bawah ini:

1. Karbon (c), pada baja-baja perkakas, prosentase karbon antara 0,1-0,6\% karbon yang juga mempengaruhi harga kekerasan dalam pembentukan fasa martensit. Selain itu kandungan karbon juga akan berpengaruh terhadap kekuatan tarik (tensile strength), keuletan (ductility), dan sifat mampu las 
(weldability) yang akan menurun apabila ada kenaikan kandungan karbon.

2. Mangan (mn), pada baja mengandung mangan karena sangat diperlukan dalam proses pembuatan baja. Kandungan mangan kurang lebih $0,6 \%$ masih belum dikatakan paduan dan tidak mempengaruhi sifat baja. Dengan bertambahnya kandungan mangan suhu kritis seimbang. Baja dengan 12\% mn adalah austenite karena itu suhu dibawah suhu kamar, akibatnya baja tidak dapat diperkeras. Unsur ini dapat berfungsi sebagai deoksiddasi dari baja dan dapat mengikat sulfur dengan membentuk senyawa mns yang titik cairnya lebih tinggi dari titik cair baja. Dengan demikian akan dapat mencegah pembentukan fe, s, yang titik cairnya lebih rendah dari titik cair baja. Akibatnya kegetasan pada suhu tinggi dapat dihindari disamping itu dapat menguatkan fasa ferit.

3. Silikon (si), Silikon berfungsi sebagai deoksidasi, silicon juga daapat menaikan hardenability dalam jumlah sedikit, tetapi dalam jumlah banyak akan menurunkan keuletan. Biasanya unsur-unsur kimia lainnya seperti mangan, molybdenum, akan muncul dengan adanya silicon. Kombinasi silicon dengan unsur-unsur tersebut akan menambah kekuatan dan ketangguhan dari baja.

4. Chromium (cr), chromium ditemukan dalam jumlah yang banyak pada baja-baja perkakas dan merupakan elemen penting setelah karbon. Chromium merupakan salah satu unsur-unsur pembentuk karbida dan dapat meningkatkan ketahanan korosi dengan membentuk lapisan oksida dipermukaan logam.

5. Nikel (ni), nikel mempunyai pengaruh yang sama seperti mangan yaitu menurunkan suhu kritis dan kecepatan pendinginan kritis. Memperbaiki kekuatan tarik, tahan korosi. Menaikkan ketangguhan atau ketahanan terhadap beban benturan (impact)

6. Vanadium (v), vanadium dalam baja-baja perkakas berperan sebagai salah satu pembentuk karbida. Vanadium juga merupakan unsure penstabil martensit. Pada saat proses temper, karbida vanadium berada dibatas butir ferrit. Hal ini akan menaikkan harga kekerasan. Biasanya terjadi pada temperatur temper $500-600^{\circ} \mathrm{C}$. Vanadium dapat menurunkan hardenability karena karbida-karbida yang lain terbentuk dapat menghambat pergantian dan pertumbuhan butir austenite. Tetapi pada temperatur tinggi, dimana karbida vanadium larut, unsur ini dapat meningkatkan hardenability.

7. Molybdenum (mo), unsur ini dapat menguatkan fasa ferrit dan menaikkan kekuatan baja tanpa kehilaangan keuletan. Molybdenum juga dapat berfungsi sebagai penyeimbang karbida sehingga dapat mencegah pembentukan grafit pada pemanasan yang lama. Karena itu penambahan mo kedalam baja dapat menaikkan kekuatan dan ketahanan terhadap creep pada suhu tinggi.

\section{Standardis asi Baja}

1. Menurut Amerika Serikat.
a. ASTM (American Society For Testing Materials)
b. AISI (Americal Iron And Steel Institute)
c. SAE (Society Of Automotive Engineers)

\section{Menurut UNS (United Numbering System) \\ b. JIS (Japan Industrial Standar) \\ c. Inggris (British Standard) \\ d. Jerman (Dine) \\ e. Swedia $\mathrm{f}$. \\ f. Indonesia (Standar Nasional Indonesia)}

\section{Pengertian Heat Treatment (Perlakuan Panas)}

Perlakuan panas atau heat treatment adalah salah satu cara yang mengakibatkan perubahan struktur bahan melalui penyolderan atau penyerapan panas: dalam bentuk bahan tetap sama (kecuali perubahan akibat regangan panas). yang disebut struktur adalah susunan dalam logam, menjadi dapat dlihat jika sekeping logam yang terasah dan teretsa (asam salpeter) diamati dibawah mikroskop. Struktur besi murni struktur semua logam terdiri atas kristal-kristal yang bergandengan kuat satu sama lain dalam wujud dan ukuran yang berlainan. Kristal-kristal itu terdiri atas bagian-bagian terkecil suatu unsur, atom-atom.

Atom besi tersusun didalam sebuah kisi-kisi/ ruang. Pengertiannya adalah sebuah wujud garis meruang yang titik-titik potongnya diduduki atomatom besi, kisi/ruang ini terdiri atas mata jaringan yang berbentuk dadu. Dalam hubungan ini ditemukan perletakan atom menurut tiga jenis:

1. Besi Alfa, delapan atom terletak pada pojok dadu dan sebuah atom ke 9 ditengah-tengah dadu (di pusat ruang). Susunan atom ini disebut juga kisi terpusat ruang sampai suhu ruangan $768^{\circ} \mathrm{C}$, besi alfa bersifat magnetis. Dari $768^{\circ} \mathrm{C}$ sampai $911^{\circ} \mathrm{C}$, besi terpusat ruang menjadi tidak magnetis dan besi

2. Besi Gamma, pada $911^{\circ} \mathrm{C}$, ikatan kisi terpusat ruang menjelma menjadi besi gamma terpusat bidang: pada setiap pojok dadu berada sebuah atom dan 6 atom lainnya berada dipertengahan ke 6 bidang bujur sangkar permukaan dadu. Karena sebuah dadu gamma menampung 14 atom, sedangkan jumlah keseluruhan atom besi tentunya 5 dan tidak akan bertambah akibat pemanasan, maka dadu gamma lebih besar dari dadualfa.

3. Besi Delta, pada $1392^{\circ} \mathrm{C}$, besi gamma yang terpusat bidang berubah wujud kembali menjadi 
besi terpusat ruang yang disebut besi delta. Besi delta berbeda dari besi alfa dalam jarak atomnya yang lebih besar.

\section{Mengenal Proses Heat Treatment}

Heat treatment adalah kombinasi dari proses pemanasan dan pendinginan dengan kecepatan tertentu yang dilakukan terhadap logam atau paduan dalam keadaan padat, sebagai suatu upaya untuk memperoleh sifat-sifat tertentu. Proses perlakuan panas pada dasarnya terdiri dari beberapa tahapan, dimulai dengan pemanasan sampai ke temperatur tertentu, lalu diikuti dengan penahanan temperature selama beberapa saat, baru kemudian dilakukan pendinginan dengan kecepatan tertentu.

\section{Klasifikasi Heat Treatment}

1. Near equilibrium (mendekati kesetimbangan) tujuan umum dari perlakuan panas jenis near equilibrium ini diantaranya adalah untuk melunakkan struktur kristal menghaluskan butir, menghilangkan tegangan dalam dan memperbaiki machineability. Jenis dari perlakukan panas near equibrium, misalnya:full annealing (annealing), stress relief annealing, process annealing, spheroidizing, normalizing dan homogenizing.

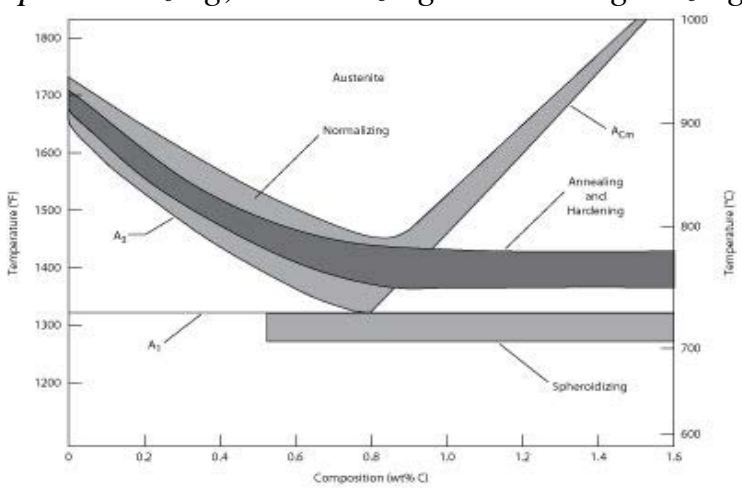

Gambar 2. Diagram Perlakuam Panas Di Garis Equilibrium

Dari sedikit penjelasan diatas dapat kita tarik benang merah bahwa secara umum proses perlakuaan dengan kondisi near equilibrium itu dapat disebut dengan anneling. Anneling adalah suatu proses perlakuan panas (heat treatment) yang sering dilakukan terhadap logam atau paduan dalam proses pembuatan suatu produk. Tahapan dari proses anneling ini dimulai dengan memanaskan logam (paduan) sampai temperatur tertentu, menahan pada temperatur tertentu tadi selama beberapa waktu tertentu agar tercapai perubahan yang diinginkan lalu mendinginkan logam atau paduan tadi dengan laju pendinginan yang cukup lambat. Jenis anneling itu beraneka ragam, tergantung pada jenis atau kondisi benda kerja, temperatur pemanasan, lamanya waktu penahanan, laju pendinginan (cooling rate), dll. Sehingga kita akan mengenal dengan apa yang disebut:
Fullannealing (annealing), stress relief annealing, process annealing, spheroidizing, normalizing dan homogenizing.

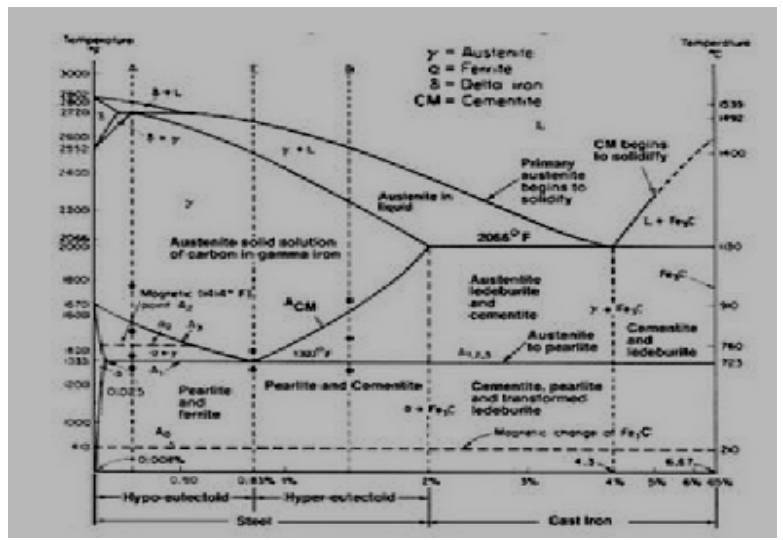

Gambar 3. Diagram Garis-Garis Equilibrium FerriteCementid (fe-fe3c)

Ferrite ialah suatu komposisi logam yang mempunyai batas maksimum kelarutan carbon 0,025\%c pada temperature $723^{\circ} \mathrm{C}$, struktur kristalnya BCC (Body Center Cubic) dan pada temperatur kamar mempunyai batas kelarutan carbon 0,008\%c.

Austenite ialah suatu larutan padat yang mempunyai batas maksimum kelarutan carbon 2\%c pada temperatur $1130^{\circ} \mathrm{C}$, struktur kristalnya FCC (Face Center Cubic).

Cementid ialah suatu senyawa yang terdiri dari unsur fe dan c dengan perbandingan tertentu (mempunyai rumus empiris) dan struktur kristalnya orthohombic.

Lediburite ialah campuran eutectic antara besi gamma dengan cementid yang dibentuk pada temperatur $1130^{\circ} \mathrm{C}$ dengan kandungan carbon $4,3 \%$ c.

Pearlite ialah campuran eutectoid antara ferrite dengan cementid yang dibentuk pada temperature $723^{\circ} \mathrm{C}$ dengan kandungan carbon 3\%c.

\section{Kandungan Carbon}

$0,008 \% \mathrm{c}=$ batas kelarutan maksimum carbon pada ferrite pada temperatur kamar, 0,025\%c = batas kelarutan maksimum carbon pada ferrite pada temperatur $723^{\circ} \mathrm{C}, 0,83 \% \mathrm{c}=$ titik eutectoid $2 \% \mathrm{c}=$ batas kelarutan carbon pada besi gamma pada temperatur $1130^{\circ} \mathrm{C}, 4,3 \% \mathrm{c}=$ titik eutectic $0,1 \% \mathrm{c}=$ batas kelarutan carbon pada besi delta pada temperatur $1493^{\circ} \mathrm{C}$.

\section{Garis-garis}

Garis liquidus ialah garis yang menunjukan awal dari proses pendinginan (pembekuan). Garis solidus ialah garis yang menunjukan akhir dari proses pembekuan (pendinginan). Garis solvus ialah garis yang menunjukan batas antara fasa padat atau solid solution. Garis acm = garis kelarutan carbon pada besi gamma (austenite) garis $\mathrm{a} 3=$ garis temperatur dimana terjadi perubahan ferrit menjadi autenite (gamma) pada pemanasan. 
Garis a1 = garis temperatur dimana terjadi perubahan austenite (gamma) menjadi ferrit pada pendinginan. Garis a0 = garis temperatur dimana terjadi transformasi magnetic pada cementid. Garis a2 = garis temperatur dimana terjadi transformasi magnetic pada ferrite.

\section{Non Equilirium (Tidak Setimbang)}

Tujuan umum dari perlakuan panas jenis nonequilibrium ini adalah untuk mendapatkan kekerasan dan kekuatan yang lebih tinggi. Jenis dari perlakuan panas non-equibrium, misalnya Hardening, martempering, austempering, surface hardening (carburizing, nitriding, cyaniding, flamehardening, induction hardening)

\section{Induction Hardening (Pengerasan Induksi)}

Pengerasan induksi adalah suatu bentuk perlakuan panas dimana bagian logam dipanaskan oleh pemanasan induksi, dan ditahan pada waktu tertentu dan kemudian quenching dengan kecepatan pendinginan tertentu. Saat logam dipadamkan mengalami transformasi fase menjadi fase martensit, meningkatkan kekerasan dan kerapuhan dari bagian tersebut.

Pengerasan induksi digunakan untuk pengerasan daerah sebagian atau permukaan tanpa mempengaruhi sifat-sifat material secara keseluruhan. Dalam pengerasan induksi, material baja karbon tersebut diletakkan di dalam kumparan listrik yang telah dialirkan arus listrik melewatinya. Hal ini memberikan energi panas pada bagian baja karbon tersebut sehingga material tersebut menjadi panas. Pemanasan tersebut tergantung pada frekuensi dan arus listrik, laju pemanasan serta kedalaman pemanasan dapat diatur. Oleh karena itu, proses ini sangat cocok untuk "heat treatment surface hardening” atau perlakuan panas permukaan material baja karbon.

\section{Proses Pemanasan Induksi}

Pemanasan induksi adalah proses pemanasan non-kontak yang memanfaatkan prinsip elektromagnetik induksi untuk menghasilkan panas di dalam lapisan permukaan sepotong material. Dengan menempatkan sebuah konduktif bahan menjadi arus listrik kuat medan magnet dapat dibuat mengalir dalam baja sehingga menciptakan panas karena i $2 \mathrm{r}$ kerugian dalam material magnetik, panas lebih lanjut yang dihasilkan di bawah titik curie karena histeresis kerugian. Arus yang dihasilkan saat ini terutama di lapisan permukaan, kedalaman lapisan ini yang ditentukan oleh frekuensi medan magnet, kekerasan permukaan densitas, kemampuan karakter material, waktu jeda penahanan panas dan diameter atau ketebalan poros. Dengan quenching lapisan ini dipanaskan dalam air, minyak atau polimer memuaskan berdasarkan lapisan permukaan diubah untuk membentuk martensit struktur yang lebih sulit dari pada logam dasar.

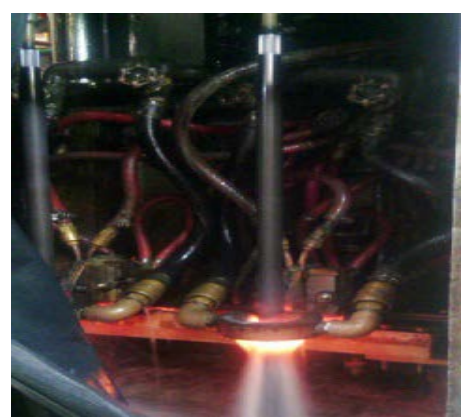

Gambar 4. Proses Induksi Hardening Pada Poros Axle Shaft

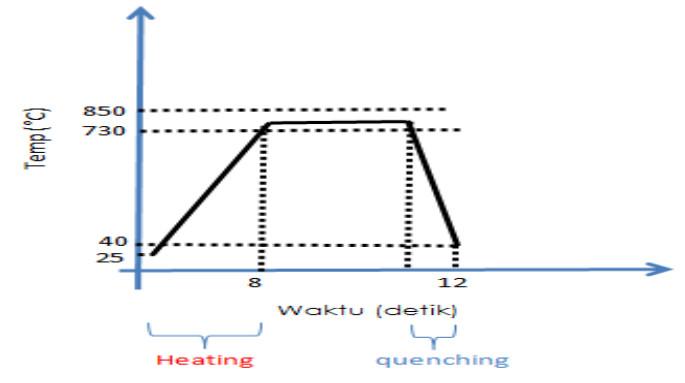

Gambar 5. Grafik Korelasi Antara Temperatur Dan Waktu Dalam Induksi Hardening

Definisi sebuah proses secara luas digunakan untuk pengerasan permukaan baja. Komponen dipanaskan dengan menggunakan medan magnet bolak-balik dengan suhu di dalam atau di atas rentang transformasi diikuti oleh pendinginan segera (seperti yang ditunjukan pada gambar 5). Inti dari material tetap tidak terpengaruh oleh perlakuan panas dan sifat fisik adalah dari bar dari mana itu mesin, sedangkan kasus kekerasan bisa berada dalam kisaran 37/58 hrc. Karbon dan baja paduan dengan kadar karbon setara dalam kisaran 0.40/0.45\% yang paling sesuai untuk proses ini.

Sebuah sumber listrik frekuensi tinggi digunakan untuk menggerakkan sebuah arus bolak besar melalui kumparan. Bagian dari arus melalui kumparan ini menghasilkan medan magnet yang sangat intens dan cepat berubah dalam ruang dalam kumparan bekerja. Benda kerja yang akan dipanaskan ditempatkan dalam medan magnet ini bolak balik intens di mana "eddy current" dihasilkan dalam benda kerja dan ketahanan menyebabkan pemanasan joule logam.

Proses ini paling umum digunakan dalam baja paduan. Kebanyakan untuk bagian mekanis, seperti poros, roda gigi, dan mata bor, menjadi sasaran induksi hardening, sebelum menyampaikan, dalam rangka meningkatkan perilaku dipakai. Efektivitas perawatan ini tergantung baik pada permukaan material modifikasi properti dan pengenalan tegangan sisa. Diantara perawatan ini, pengerasan induksi adalah salah satu yang paling banyak digunakan untuk meningkatkan komponen daya 
tahan. Ini menentukan dalam lembaran kerja inti yang tangguh dengan tegangan sisa tarik dan lapisan permukaan keras dengan tegangan tekan, yang telah terbukti sangat efektif dalam memperpanjang komponen kelelahan hidup dan ketahanan aus .

Proses induksi hardening pada paduan baja karbon saat ini banyak digunakan untuk aplikasi otomotif dan komponen-kompones kritis pada konstruksi mesin dimana membutuhkan sifat material untuk ketahanan aus yang tinggi.

Penggunaan proses perlakuan panas induksi hardening tergantung pada kedalaman penetrasi, ukuran material, dan distribusi stress material akibat tegangan sisa pada lapisan permukaan.

\section{Se jarah Pemanas an Induksi}

Awal dari semua sistem pemanas induksi ditemukan pada tahun 1831 oleh michael faraday. Faraday membuktikan bahwa dengan menggulungnya dua gulungan kawat di sekitar inti magnetik yang umum adalah mungkin untuk menciptakan sesaat garis gaya listrik (ggl) di kedua lilitan kawat dengan beralih dari arus listrik pada lilitan pertama dan berakhir. Dia lebih jauh mengamati bahwa jika arus dijaga konstan, tidak ada ggl induksi pada kedua gulungan dan bahwa arus ini mengalir dalam arah berlawanan tergantung apakah arus yang dinaikan atau diturunkan dalam rangkaian. Faraday menyimpulkan bahwa arus listrik dapat dihasilkan oleh medan magnet yang berubah. Karena tidak ada kontak fisik antara gulungan primer dan sekunder, ggl pada kumparan sekunder dikatakan diinduksi dan begitulah isi hukum induksi faraday lahir. Setelah ditemukan, prinsip-prinsip yang bekerja selama abad berikutnya atau lebih di desain dinamo (generator listrik dan motor listrik, yang merupakan varian dari hal yang sama) dan dalam bentuk listrik transformator. Dalam aplikasi ini, panas yang dihasilkan pun baik di dalam sirkuit listrik atau magnet dirasakan tidak dikehendaki. Para ahli engineering berusaha sebaik mungkin sehingga dapat digunakan lapisan core dan metode lain untuk meminimalis ir efek panas tersebut.

Awal abad terakhir prinsip-prinsip induksi dieksplorasi penggunaannya sebagai alat untuk mencairkan baja, dan generator motor dikembangkan untuk menyediakan daya yang diperlukan untuk tungku induksi. Hal ini sudah dipahami bahwa kedalaman penetrasi saat ini di baja adalah fungsi dari permeabilitas magnet, resistivitas dan frekuensi medan listrik. Para ahli engineering dari "midvale steel dan the ohio crankshaft", perusahaan yang tertarik pada ilmu pengetahuan ini mengembangkan "flame induction hardening" pertama pada sistem pemanas yang menggunakan motor generator.

Kebutuhan sistem otomatis secara mudah dan cepat mengakibatkan kemajuan besar dalam pemahaman dan pemanfaatan proses pemanasan induksi. Banyak system proses produksi pada akhir 1950-an memanfaatkan generator motor dan emisi termionik triode osilator yang digunakan biasa dalam array dari industri. Saat ini pemanasan induksi unit modern memanfaatkan teknologi terbaru dalam semikonduktor dan sistem kontrol digital untuk mengembangkan berbagai daya dari 1 kw hingga banyak megawatt.

\section{Metode Principal}

\section{Pengeras an Bidik Tembakan Tunggal}

Dalam sistem tembakan tunggal komponen tersebut dilakukan secara statis atau dirotasi dalam kumparan dan daerah keseluruhan untuk diperlakukan dipanaskan secara bersamaan untuk waktu yang telah ditetapkan sebelumnya diikuti dengan baik memuaskan banjir atau sistem memuaskan drop. Bidik sering digunakan dalam kasus-kasus di mana tidak ada metode lain yang akan mencapai hasil yang diinginkan misalnya untuk pengerasan permukaan datar dari palu, pengerasan ujung alat berbentuk kompleks atau produksi roda gigi kecil.

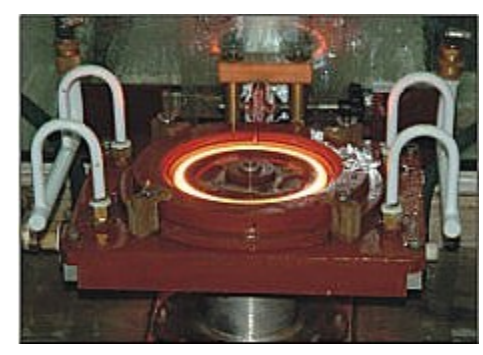

Gambar 6. Single Shoot Hardening

Dalam kasus pengerasan poros keunggulan lebih lanjut dari metodologi tembakan tunggal adalah waktu produksi dibandingkan dengan metode pengerasan melintasi progresif. Selain itu kemampuan untuk menggunakan gulungan yang dapat membuat aliran arus dalam komponen longitudinal daripada aliran diametral bisa menjadi keuntungan dengan geometri yang tertentu.

Ada kerugian dengan pengerasan tembakan tunggal. Desain koil bisa menjadi sangat kompleks dan tersulit. Kelemahan lain adalah bahwa lebih banyak daya yang diperlukan karena luas permukaan meningkat dipanaskan dibandingkan dengan pengerasan traverse.

\section{Pengerasan Traverse}

Dalam sistem ini pengerasan benda kerja dilewatkan melalui kumparan induksi secara cepat dan disemprotkan quenching kemudian dari koil yang berbentuk ring. Pengerasan traverse kebanyakan digunakan dalam produksi komponen tipe poros seperti poros gardan, komponen diumpankan melalui induktor jenis dering yang biasanya fitur tunggal. Lebar dari belokan ditentukan oleh kecepatan traverse, daya yang tersedia dan 
frekuensi generator. Hal ini menciptakan sebuah band bergerak dari panas yang saat dipadamkan menciptakan lapisan permukaan mengeras. Dengan memvariasikan kecepatan dan kekuatan adalah mungkin untuk membuat poros yang dikeraskan keseluruhan panjangnya atau hanya di daerah tertentu dan juga untuk mengeras poros dengan langkah diameter atau splines. Ini adalah normal bila pengerasan poros putaran untuk memutar bagian, selama proses untuk memastikan setiap variasi karena konsentrisitet dari kumparan dan komponen akan dihapus.

\section{Peralatan}

\section{Kebutuhan Power (Daya)}

Pasokan daya untuk pengerasan induksi bervariasi dalam daya dari beberapa kilowatt, ratusan kilowatt tergantung dari ukuran material yang akan dipanaskan dan metode produksi yang digunakan yaitu hardening tembakan tunggal, pengerasan melintasi atau pengerasan terendam.

Untuk memilih power supply yang sesuai pertama-tama perlu untuk menghitung luas permukaan komponen yang akan dipanaskan. Lalu setelah itu telah diperhintungkan maka pertimbangan metode yang digunakan agar dapat menghitung densitas daya yang diperlukan, waktu panas dan frekuensi generator operasi. Secara tradisional ini dilakukan menggunakan serangkaian grafik, kompleks empiris perhitungan dan pengalaman. Teknik modern biasanya menggunakan analisis elemen hingga dan dibantu manufaktur komputerisasi, tetapi dengan semua metode seperti itu tetap saja ilmu pengetahuan menyeluruh tentang proses pemanasan induksi masih diperlukan.

Untuk aplikasi tembakan tunggal luas areal yang perlu dipanaskan untuk dihitung. Dalam kasus pengerasan melintasi lingkar komponen dikalikan dengan lebar permukaan kumparan. Perawatan harus dilakukan ketika memilih lebar permukaan kumparan yang praktis untuk memilih kumparan yang lebar dimana akan membutuhkan daya yang sesuai saat aplikasi.

\section{Frekuensi}

Sistem pemanas induksi untuk pengerasan tersedia dalam berbagai frekuensi operasi yang berbeda biasanya dari 1 khz sampai 400 khz. Hanya frekuensi tertinggi dan terendah yang tersedia, tetapi biasanya frekuensi ini digunakan untuk aplikasi khusus. Hubungan antara frekuensi operasi dan kedalaman penetrasi saat ini dan karena kedalaman kekerasan adalah berbanding terbalik. Yaitu menurunkan frekuensi yang lebih dalam kasus ini.
Tabel 2. Hubungan Perbandingan Kedalaman (Penetrasi) Dan Frekuensi Induksi

\begin{tabular}{|c|c|c|}
\hline $\begin{array}{c}\text { Kedalaman } \\
\text { hardening [mm] }\end{array}$ & $\begin{array}{c}\text { Diameter } \\
\text { batang [mm] }\end{array}$ & $\begin{array}{c}\text { Frekuensi } \\
\text { [khz] }\end{array}$ \\
\hline $0,8-1,5$ & 5 sampai 25 & 200 hingga 400 \\
\hline \multirow{2}{*}{$1,5-3,0$} & 10 sampai 50 & 10 hingga 100 \\
\cline { 2 - 3 } & $>50$ & 3 hingga 10 \\
\hline \multirow{3}{*}{$3-10$} & 20 sampai 50 & 3 hingga 10 \\
\cline { 2 - 3 } & 50 sampai 100 & 1 hingga 3 \\
\cline { 2 - 3 } & $>100$ & 1 \\
\hline
\end{tabular}

Pada tabel 2. di atas adalah ilustrasi murni, hasil yang baik dapat diperoleh di luar nilai diatas dengan menyeimbangkan power, frekuensi dan pertimbangan lain termasuk nilai yang dapat mempengaruhi hasil akhir, waktu penahanan panas dan jarak coil. Serta kerapatan daya dan frekuensi, waktu pemanasan materialakan mempengaruhi kedalaman panas akan berpindah dengan cara konduksi. Waktu di koil dapat dipengaruhi oleh kecepatan lintasan dan jarak koil, namun hal ini juga akan berefek pada kebutuhan daya keseluruhan atau peralatan langsung.

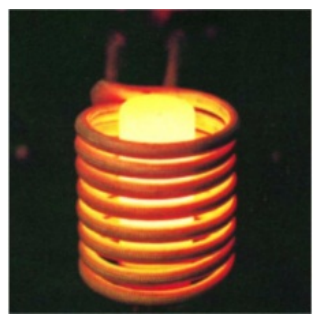

Gambar 7. Pemanas Induksi Pencair Logam

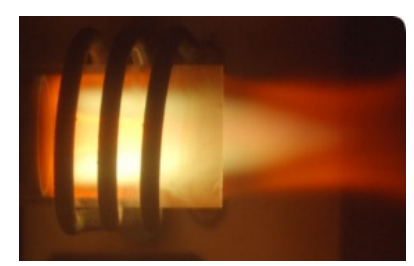

Gambar 8. Pemanas Induksi Pada Proses Plasma

\section{Flame hardening}

Flame hardening atau pengerasan dengan nyala api terbuka adalah pengerasan yang dilakukan dengan memanaskan benda kerja pada nyala api. Nyala api tersebut dapat menggunakan elpiji + udara atau acetylin + O2. Permukaan benda kerja dipanaskan hingga suhu diatas suhu kritis atas, dengan cara menjalankan api oxy-acetylene dan segera didinginkan dengan semprotan air. Cara ini sangat efektif untuk baja dengan kandungan karbon cukup tinggi (lebih dari 0,4\%c). Sebelum diperkeras sebaiknya komponen dinormalising, sehingga didapat permukaan kulit dengan struktur martensit ( \pm sedalam $4 \mathrm{~mm}$ ) dan inti ferrite-pearlite yang ulet. Dalam hal ini tempering juga diperlukan, baik dengan nyala api ataupun dalam dapur tempering. Untuk mengetahui berapa temperaturnya, biasanya disesuaikan dengan tabel warna yang dikeluarkan 
oleh pabrik baja dalam buku manual. Warna-warna tabel tersebut berkisar antara:

A. $200-300^{\circ} \mathrm{C}$ untuk warna temper

B. $600-1300^{\circ} \mathrm{C}$ untuk warna pijar/pengerasan

\section{Karburasi}

Cara ini sudah lama dikenal oleh orang sejak dulu. Dalam cara ini, besi dipanaskan di atas suhu dalam lingkungan yang mengandung karbon, baik dalan bentuk padat, cair ataupun gas. Beberapa bagian dari cara kaburasi yaitu kaburasi padat, kaburasi cair dan karburasi gas.

\section{Karbonitriding}

Adalah suatu proses pengerasan permukaan dimana baja dipanaskan diatas suhu kritis di dalam lingkungan gas dan terjadi penyerapan karbon dannitrogen. Keuntungan karbonitiding adalah kemampuan pengerasan lapisan luarmeningkat bila ditambahkan nitrogen sehingga dapat dimanfaatkan baja yang relative mudah dengan ketebalan lapisan yang keras antara 0,80 sampai $0,75 \mathrm{~mm}$.

\section{Sianiding}

Adalah proses dimana terjadi absobsi karbon dan nitrogen untuk memperoleh specimen yang keras pada baja karbon rendah yang sulit dikeraskan.

\section{Nitriding}

Adalah proses pengerasan permukaan yang dipanaskan sampai $\pm 510^{\circ} \mathrm{C}$ dalam lingkungan gas ammonia selama beberapa waktu.

\section{Proses Quenching}

\section{Mengenal Proses Quenching}

Proses quenching adalah proses perlakuan panas dan dingin dengan laju pendinginan yang cepat dan dilakukan pada suatu media misalkan: air atau oli untuk memperoleh sifat mekanik yang lebih keras. media pendingin tersebut antara lain: a. Air, b. Oli, c. Salth bath, d. Air garam.

\section{Heat Treatment Dengan Quenching Menerus}

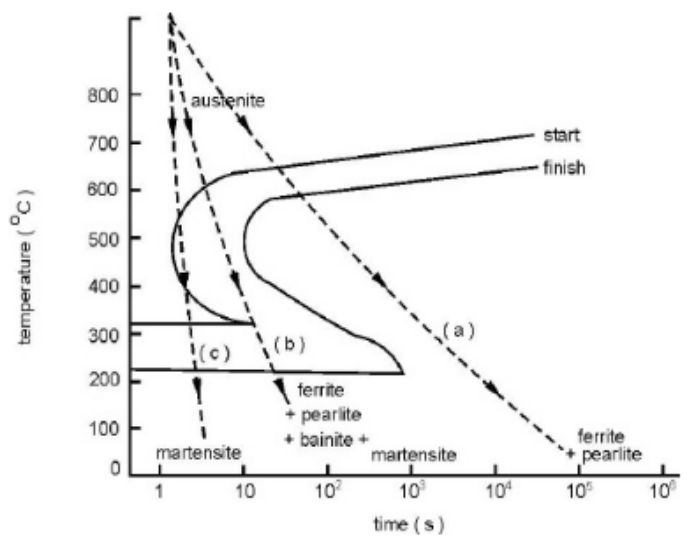

Gambar 9. Continuos Cooling Transformation Diagram
Penjelasan diagram:

A. Pada proses pendinginan secara perlahan seperti pada garis (a) akan menghasilkan struktur mikro perlit dan ferlit.

C. pada proses pendinginan sedang, seperti, pada garis (b) akan menghasilkan struktur mikro perlit dan bainit.

D. Pada proses pendinginan cepat, seperti garis (c) akan menghasilkan struktur mikro martensit

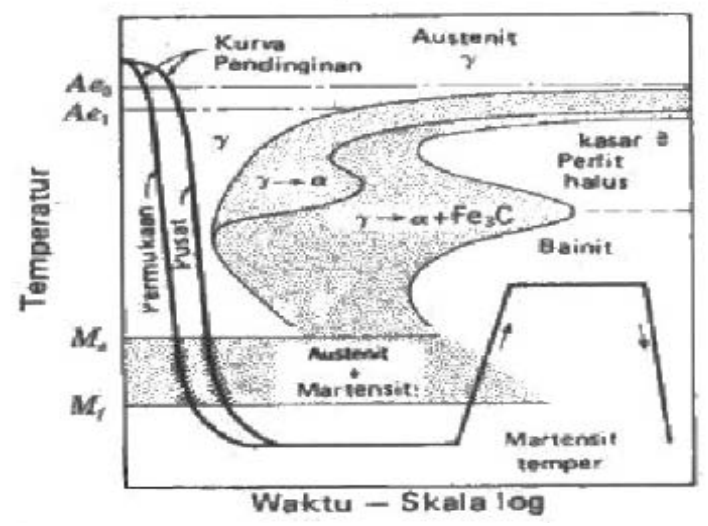

Gambar 10. Diagram Transformasi Fasa Saat Quenching

\section{Metode Pengujian Kekerasan Vickers}

Pengujian kekerasan dengan metode vickers bertujuan menentukan kekerasan suatu material dalam bentuk daya tahan material terhadap intan berbentuk piramida dengan sudut puncak 136 derajat yang ditekankan pada permukaan material uji tersebut.

Angka kekerasan vickers (hv) didefinisikan sebagai hasil bagi (koefisien) dari beban uji (f) dalam kgf yang dikalikan dengan angka faktor 0,1854 dan luas permukaan bekas luka tekan (injakan) bola baja (a) dalam $\mathrm{mm}^{2}$. Secara matematis dan setelah disederhanakan, hv sama dengan 1,854 dikalikan beban uji (f) dibagi dengan diagonal intan yang dikuadratkan. Beban uji (f) yang biasa dipakai adalah $5 \mathrm{kgf}$ per 0,1854; 10kgf per 0,1854; $30 \mathrm{kgf}$ per 0,1854 kgf dan $50 \mathrm{kgf}$ per 0,1854 .

$$
\begin{aligned}
& d=\frac{d_{1}+d_{2}}{2} \\
& H V=0,1854 \frac{F}{d^{2}}
\end{aligned}
$$
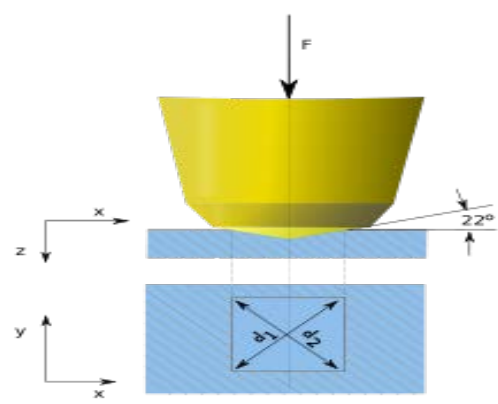

Gambar 11. Penetrator Vickers 
Dalam prakteknya, pengujian vickers biasa dinyatakan dalam (contoh): hv 30 hal ini berarti bahwa kekerasan vickers hasil pengujian dengan beban uji (f) sebesar 30 kgf per 0,1854 dan lama pembebanan 15 detik. Contoh lain misalnya hv 30/30 hal ini berarti bahwa kekerasan vickers hasil pengujian dengan beban uji (f) sebesar 30 kgf per 0,1854 dan lama pembebanan 30 detik.
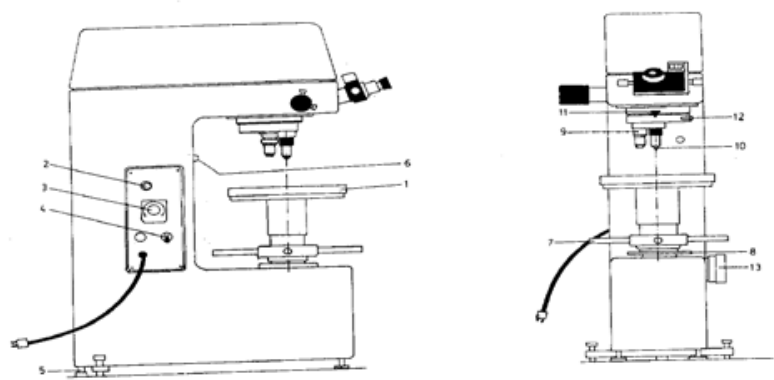

Gambar 12. Mesin Uji Hardness Metode Vickers Keterangan :
1. Meja Datar
6. Lampu Kontrol
11. Stoper
2. Tombol Variable Resistor
7. Handle Alas Meja
12. Handle
3. Potensio Timer
8. Tombol Start
4. Power Swicth ( $\mathrm{On} / \mathrm{Off})$
9. Lensa Obyektif
5. Pengatur Keseimbangan
10. Identor / Penetrator

\section{Kekerasan Vickers}

Pada umumnya, kekerasan menyatakan ketahanan terhadap deformasi, dan untuk logam dengan sifat tersebut merupakan ukuran ketahanannya terhadap deformasi plastik atau deformasi permanen. kekerasan suatu logam dipengaruhi oleh kadar karbon yang terkandung didalam logam tersebut. semakin besar kadar karbon yang terkandung maka logam tersebut semakin keras dan getas. pengukuran kekerasan suatu logam dapat dilakukan dengan cara goresan (scratch hardness), lekukan/identasi (identation hardness), dan pantulan (rebound) atau dinamik (dynamik hardness).

Angka kekerasan piramida intan (Dph), atau angka kekerasan vickers (Vhn Atau Vph) dengan satuan hardness vickers (Hv), didefinisikan sebagai beban dibagi luas permukaan lekukan yang dihitung dari pengukuran mikroskopik panjang diagonal jejak. dph dapat ditentukan dari persamaan berikut:

$$
D P H=\frac{2 P \sin (\theta / 2)}{L^{2}}=\frac{1.854 P}{L^{2}}
$$

Dimana:

$D p h=$ Angka Kekerasan Piramida Intan (Hv)

$P \quad=$ Beban yang Diterapkan $(\mathrm{Kg})$

$L \quad=$ Panjang Diagoanal rata-rata $(\mathrm{Mm})$

METODE PENGUJIAN DAN DATA

Metode Pengujian Kedalaman Penetrasi Kekerasan Efektif

Berikut ini adalah flowchart alur proses analisa hardening prosesn axle shaft jenis material s-43 pada proses induksi hardening yang penulis lakukan:

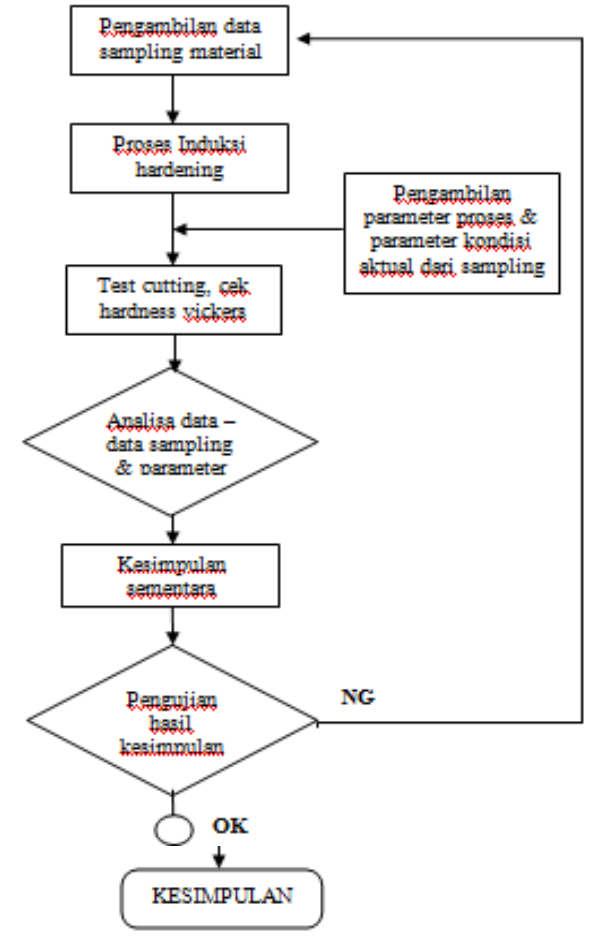

Gambar 13. Flowchart Penyelesaian Masalah

Metode pengujian kedalaman penetrasi hasil kekerasan efektif pada proses induksi hardening di PT.X ini menggunakan jenis destruktif test/ cutting test pada sampling unit pertama setelah perubahan parameter atau penyetelan. Untuk mendapatkan parameter keakuratan hasil pengujian, maka pengujian hasil akan dilakukan dengan mengikuti metode sebagai berikut:

1. Pengujian dilakukan pada sample unit pertama setelah perubahan parameter/setting parameter mesin.

2. Pengujian menggunakan test cutting (destruktif test). Specimen diukur kekerasannya menggunakan metode vickers.

3. Hasil pengukuran tersebut akan diukur dengan minimal 2 titik sebagai perbandingan kedalaman penetrasi efektif, lalu titik tersebut dihubungkan dengan perhitungan metode interpolasi antara surface hardness check (pengecekan kekerasan permukaan) dengan effective depth hardness (kedalaman penetrasi kekerasan).

4. Area pengukuran specimen sample pada area spline, karena sering bermasalah terhadap kualitas akibat tingginya variasi kedalaman kekerasan efektif pada material.

5. Data pengujian diambil dari sample material, dan parameter proses dari input aktual di mesin proses hardening jenis "k 1080 kora neturent tahun 2010“ dengan kode mesin hardening 12-9.b 


\section{Parameter Dan Batasan Pengujian Kedalaman Kekerasan Efektif}

Parameter pengujian kedalaman kekerasan efektif (untuk poros axle shaft jenis material s-43) yang dijadikan acuan dalam pengujian ini terdiri dari:

A. Metode pengujian material

1. Hardness of suface dengan metode pengujian vickers

2. Effective hardness depth dengan satuan millimeter dan hv min 400

B. Parameter mesin harden 12-9 b

1. Timer dengan satuan second

2. Speed dengan satuan $\mathrm{mm} / \mathrm{s}$

3. Power dengan satuan $\mathrm{kw}$

4. Position koil dengan satuan millimeter

5. Quenching flow dengan satuan liter/menit

6. Q.w pressure dengan satuan $\mathrm{kgf} / \mathrm{cm}^{2}$

7. Q.w temp satuannya ${ }^{\circ} \mathrm{C}$

8. C.w pressure satuannya $\mathrm{kgf} / \mathrm{cm}^{2}$

9. C.w temp satuannya ${ }^{\circ} \mathrm{C}$

10. Coil gap satuannya milimeter

Untuk mendapatkan hasil pengujian yang tepat dan dengan tingkat keakurasian yang tinggi maka pengambilan data pada contoh unit pertama setelah mesin dilakukan perubahan settingan saat produksi poros axle shaft untuk model d-01.n jenis material s43 dimana model ini digunakan untuk komponen mobil dengan merk new toyota avanza vvt-i produksi tahun 2013 yang diproduksi pada line axle shaft d kode mesin hardening 12-9.b.

\section{Peralatan Pengujian}

Dalam proses pengujian ini terdapat dua tahapan proses dan peralatan-peralatan yang digunakan pada 2 tahapan proses tersebut antara lain:

A. Proses hardening

1. Mesin hardening 12-9 b dengan merk "kora neturen" manufaktur di jepang tahun 2010

2. Koil hardening model d-01n

3. Aqua quench

4. Feller gauge

B. Proses inspeksi

1. Mesin speed cutter

2. Alat vickers hardness tester

3. Mesin grinding speed belt

\section{Prosedur Proses dan Pengujian Induksi Hardening}

Pada proses induksi hardening di mesin hardening 12-9.b melewati beberapa tahapan proses. Sequences proses pada mesin hardening.

Berdasarkan gambar 14, sequences proses yang akan peneliti bahas dipenelitian ini adalah proses auto, dimana proses auto tersebut memiliki 3 sequences proses yang saling berhubungan dan

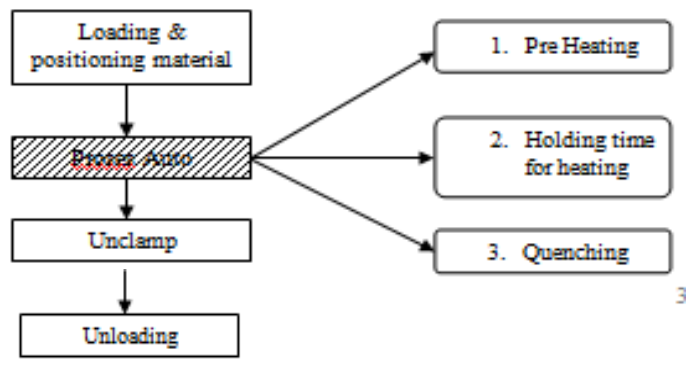

Gambar 14. Diagram Sequences Proses Hardening Induksi 12-9.b

berkaitan terhadap hasil kedalaman kekerasan efektif material. Parameter- parameter yang menjadi acuan pada sequences proses auto tersebut antara lain

1. Pre heating, dengan penyetelan parameter timer \& power

2. Holding time dengan penyetelan parameter speed

3. Quenching dengan parameter quenching flow

Pengambilan sample data dilakukan 3 kali, dengan waktu yang berbeda juga. Hal ini dimaksudkan agar mewakili kondisi mesin sesuai kondisinya yang berbeda-beda, yang juga berpengaruh terhadap parameter kondisi mesin yang berbeda juga. Sebagai pertimbangan dalam penyetelan parameter mesin, parameter dalam mesin induksi hardening "1080 kora neturent kode mesin 12-9.b” ada 2 macam,

Sampling pertama adalah parameter sebelum trial/ saat regular proses dimana hasil kedalaman penetrasi kekerasan efektifnya sudah sesuai tuntutan kualitas produksi. Dengan data parameter sebagai berikut:

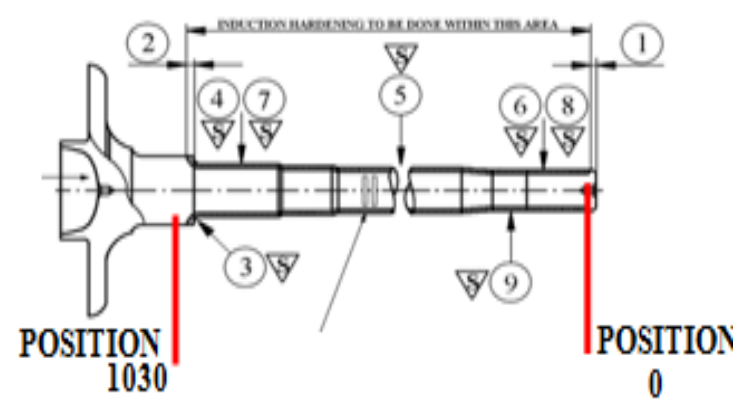

Tabel 3. Sampling 1 model DOIN

Gambar 15. Area Prose Induksi Hardening Dan Posisinya Pada Parameter Mesin 


\section{A. Sampling 1 (31-05-2013) Model D01N}

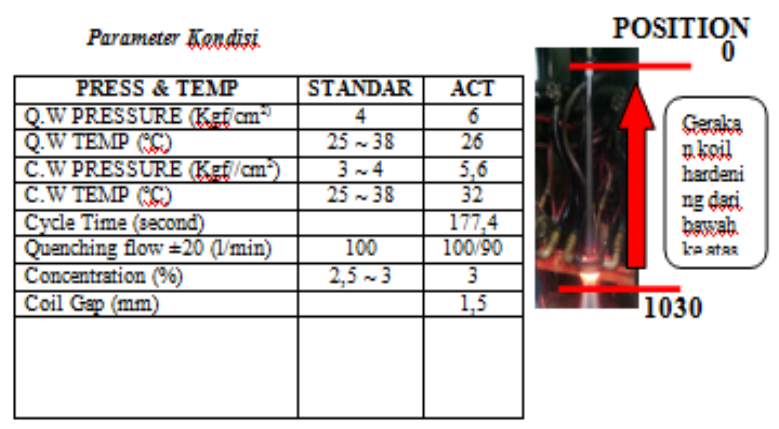

\begin{tabular}{|c|c|c|c|c|c|c|}
\hline \multirow{2}{*}{ POS(mm) } & \multicolumn{2}{|c|}{ Timer $(\mathrm{sec})$} & \multicolumn{2}{|c|}{ Speed $(\mathrm{mm} / \mathrm{s})$} & \multicolumn{2}{|c|}{ Power(KWV) } \\
\hline & STD & ACT & STD & ACT & STD & ACT \\
\hline 867,6 & 0 & 0 & 5,0 & 0 & 0 & 0 \\
\hline 867,6 & 2,1 & 2,1 & 0 & 0 & 165 & 164 \\
\hline 857 & 0 & 0 & 3,5 & 0 & 0 & 0 \\
\hline 856 & 0 & 0 & 5,3 & 5,2 & 165 & 164 \\
\hline 809 & 0 & 0 & 7,3 & 7,2 & 165 & 164 \\
\hline 209 & 0 & 0 & 7,8 & 7,7 & 165 & 164 \\
\hline 135,2 & 0 & 0 & 8,2 & 8,1 & 160 & 159 \\
\hline 100 & 0 & 0 & 30 & 28,2 & 0 & 0 \\
\hline 100 & 8,0 & 8,0 & 0 & 0 & 0 & 0 \\
\hline
\end{tabular}

Tabel 5. Sampling 3 model DOIN

Parameter Kondisi.
\begin{tabular}{|l|c|c|}
\hline \multicolumn{1}{|c|}{ PRESS \& TEMP } & STANDAR & ACT \\
\hline Q.W PRESSURE (Kgf $\left.\mathrm{cm}^{2}\right)$ & 4 & 5 \\
\hline Q.W TEMP ("C) & $24 \sim 28$ & - \\
\hline C.W PRESSURE (Kgf/ $\left./ \mathrm{cm}^{2}\right)$ & 4 & 4,6 \\
\hline C.W TEMP ("C) & $25 \sim 38$ & 34 \\
\hline Cycle Time (sacond) & & 173,3 \\
\hline Quenching flow $\pm 20(\mathrm{~m} / \mathrm{min})$ & & $85 / 100$ \\
\hline Concentration (\%) & $3 \sim 4$ & 3,5 \\
\hline Coil Gap (mm) & & 1,5 \\
\hline & & \\
\hline
\end{tabular}

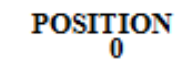

Berdagrkan 3 data sampling diatas, sengaig diambil dengan walth

berbeda dengan maksud untuk mendapatkan hasil proses yang menvalili sampling produlsai, attugl.

Aildoiparameter proses posisi
\begin{tabular}{|c|c|c|c|c|c|c|}
\hline \multirow{2}{*}{ POS(mm) } & Timer (sec) & \multicolumn{2}{c|}{ Speed(mm/s) } & \multicolumn{2}{c|}{ Power(KW) } \\
\cline { 2 - 7 } & STD & ACT & STD & ACT & STD & ACT \\
\hline 1025,3 & 0 & 0 & 3 & 0 & 0 & 0 \\
\hline 1025,3 & 1,5 & 1.5 & 0 & 0 & 120 & 131 \\
\hline 1018 & 0 & 0 & 25 & 0 & 0 & 0 \\
\hline 1016 & 0 & 0 & 3,6 & 3,5 & 125 & 130 \\
\hline 931 & 0 & 0 & 6,8 & 6,7 & 110 & 122 \\
\hline 393 & 0 & 0 & 6,0 & 5,9 & 110 & 119 \\
\hline 293 & 0 & 0 & 6,3 & 6,2 & 110 & 114 \\
\hline 275 & 0 & 0 & 25 & 24,9 & 0 & 0 \\
\hline 253 & 0 & 0 & 25 & 24,9 & 0 & 0 \\
\hline 253 & 15 & 15 & 0 & 0 & 0 & 0 \\
\hline
\end{tabular}

\section{Data Hasil Pengujian}

Berdasarkan parameter aktual yang diinput /terdapat pada mesin hardening 12-9 b, maka sample benda kerja tersebut diambil data penetrasi kedalaman kekerasan efekitfnya. Pengujian hasil kedalaman penetrasi tersebut menggunakan methode initial test cutting (destructive test). Dan menggunaakan metode vickers untuk mengukur tingkat kekerasan materialnya, berikut adalah urutan proses pengecekan hasil pengujian kedalaman penetrasi kekerasan efektifnya

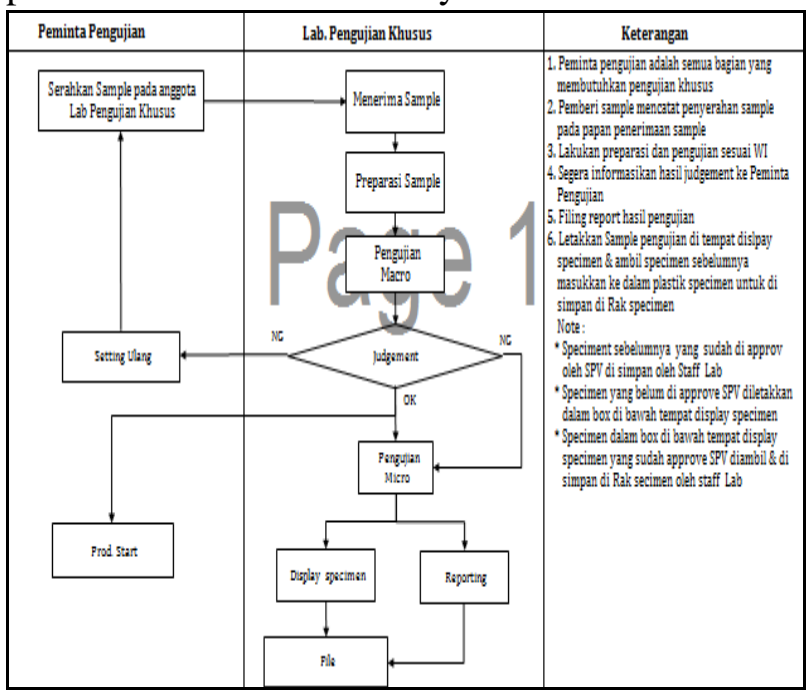

Gambar 16. Diagram Sequences Proses Pengujian Hasil Hardening Induksi 12-9.b

Berdasarkan hasil pengujian 3 data sample diatas. Maka berikut didapat hasil penetrasi kedalaman efektif dengan standar kekerasan efektif minimal 400 hv (hardness Vickers).

Tabel 6. Evaluasi Sampling 1 model DOIN

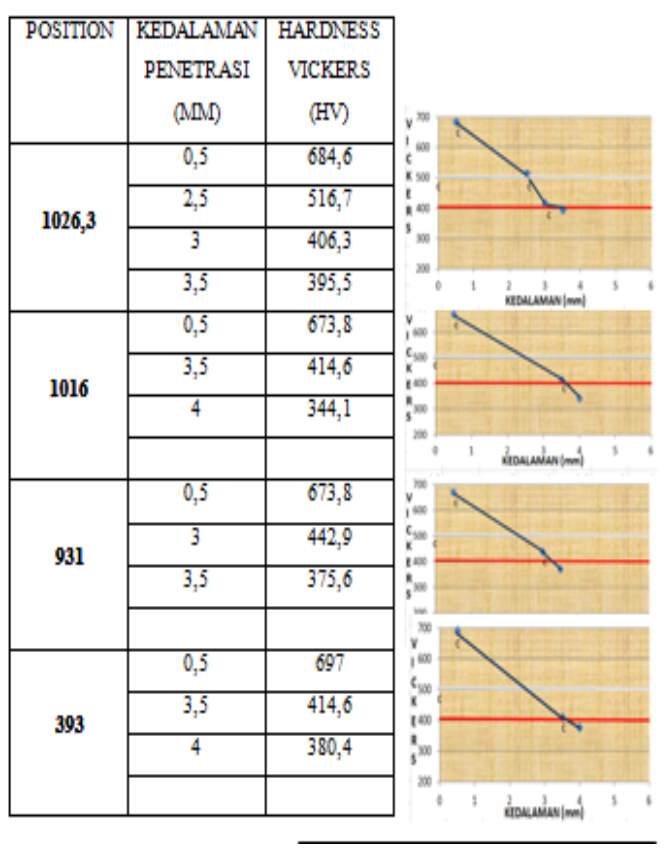




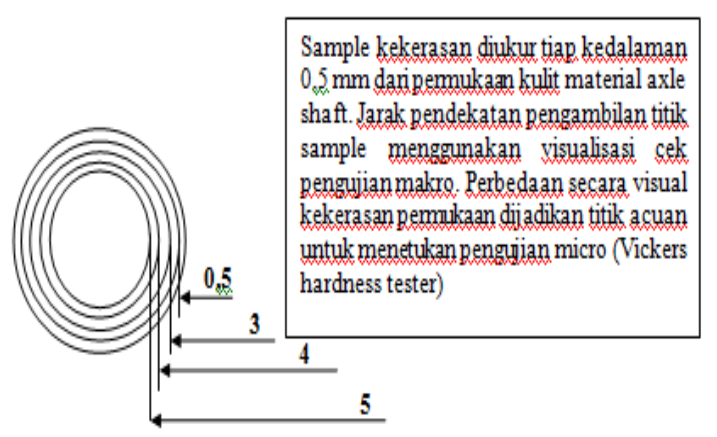

Tabel 7. Evaluasi Sampling 2 Model DOIN

\begin{tabular}{|c|c|c|}
\hline POSITION & $\begin{array}{c}\text { KEDALAMAN } \\
\text { PENETRASI } \\
\text { (MM) }\end{array}$ & $\begin{array}{l}\text { HARDNESS } \\
\text { VICKERS } \\
\text { (HV) }\end{array}$ \\
\hline \multirow{3}{*}{867,6} & 0,5 & 685,3 \\
\hline & 4 & 474,3 \\
\hline & 4,5 & 395,5 \\
\hline \multirow{3}{*}{809} & 0,5 & 697 \\
\hline & 5 & 455,1 \\
\hline & 5,5 & 324 \\
\hline \multirow{3}{*}{209,1} & 0,5 & 697 \\
\hline & 3 & 501,9 \\
\hline & 3,5 & 380,4 \\
\hline \multirow{4}{*}{133,6} & 0,5 & 709,5 \\
\hline & 4 & 431,2 \\
\hline & 4,5 & 344,1 \\
\hline & & \\
\hline
\end{tabular}

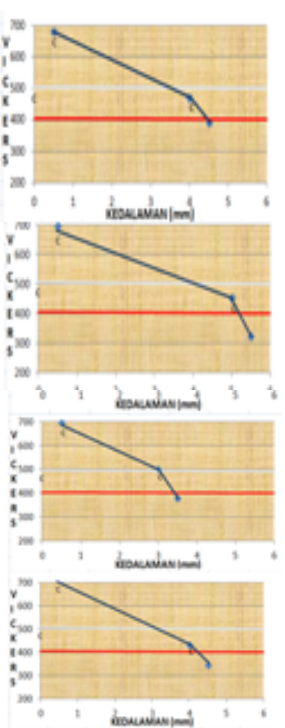

Tabel 8. Evaluasi Sampling 3 Model DOIN

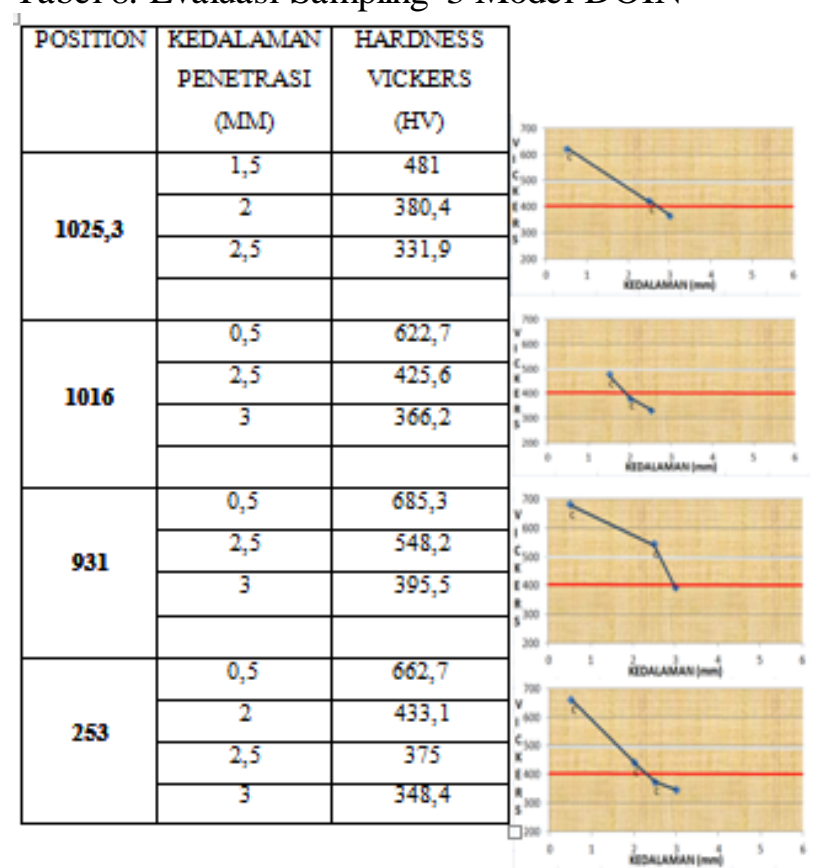

\section{ANALISIS DATA DAN PEMBAHASAN}

Pada analisis data dibawah ini, sengaja diambil dalam waktu yang berbeda dengan kondisi yang sama yaitu saat setting awal ganti model produksi massal. Hal ini bertujuan untuk mendapatkan analisa data yang lebih objektif dan mewakili sebagian besar problem-problem saat penyetelan awal mc 12-9.b.

\section{Metode Pengujian Kedalaman Penetrasi Kekerasan Efektif}

Dalam metode pengujian kedalaman penetrasi kekerasan efektif permukaan menggunakan metode vickers karena sesuai tuntutan Standar Quality Check mc 12-9.b yang ada. Untuk mengukur tingkat kekerasan hardness permukaan dengan metode vickers setelah terbaca di mesin lalu hasil tersebut dihitung dengan rumus:

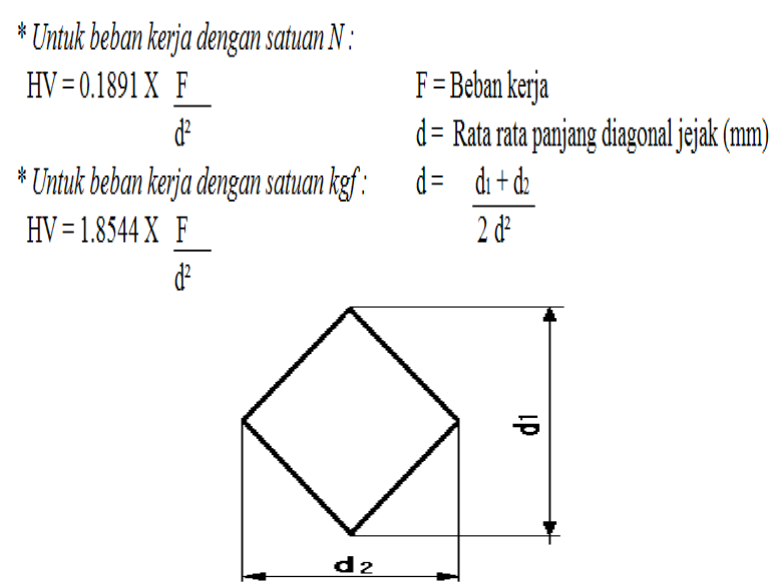

Gambar 17. Bentuk Jejak Pengujian Vickers

Contoh salah satu perhitungan vickers untuk sample 1 pada posisi 1026,3

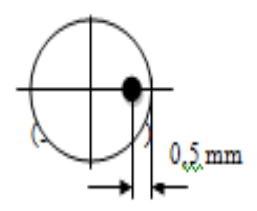

$$
\begin{aligned}
& \text { Diket } \mathrm{F}=50 \mathrm{~kg} \\
& d=d 1+d 2 / \quad \text { Dit: H Hickers, } \\
& =0,383+0,353 / 2 \quad=684.6 \mathrm{HV} \\
& =0,368 \mathrm{~mm}
\end{aligned}
$$

\section{Analisis Perbandingan Hasil Kedalaman Penetrasi Kekeras an Efektif}

Agar mendapatkan hasil yang lebih efektif dan lebih tepat maka untuk mencari hardness vickers menggunakan tabel yang sudah tersedia sesuai beban yang diberikan. Dari tabel dapat kita peroleh hasil :

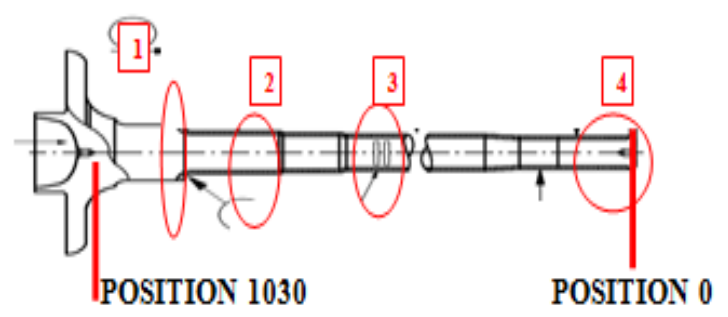

Gambar 18. Posisi Area Proses Poros Axle Shaft 

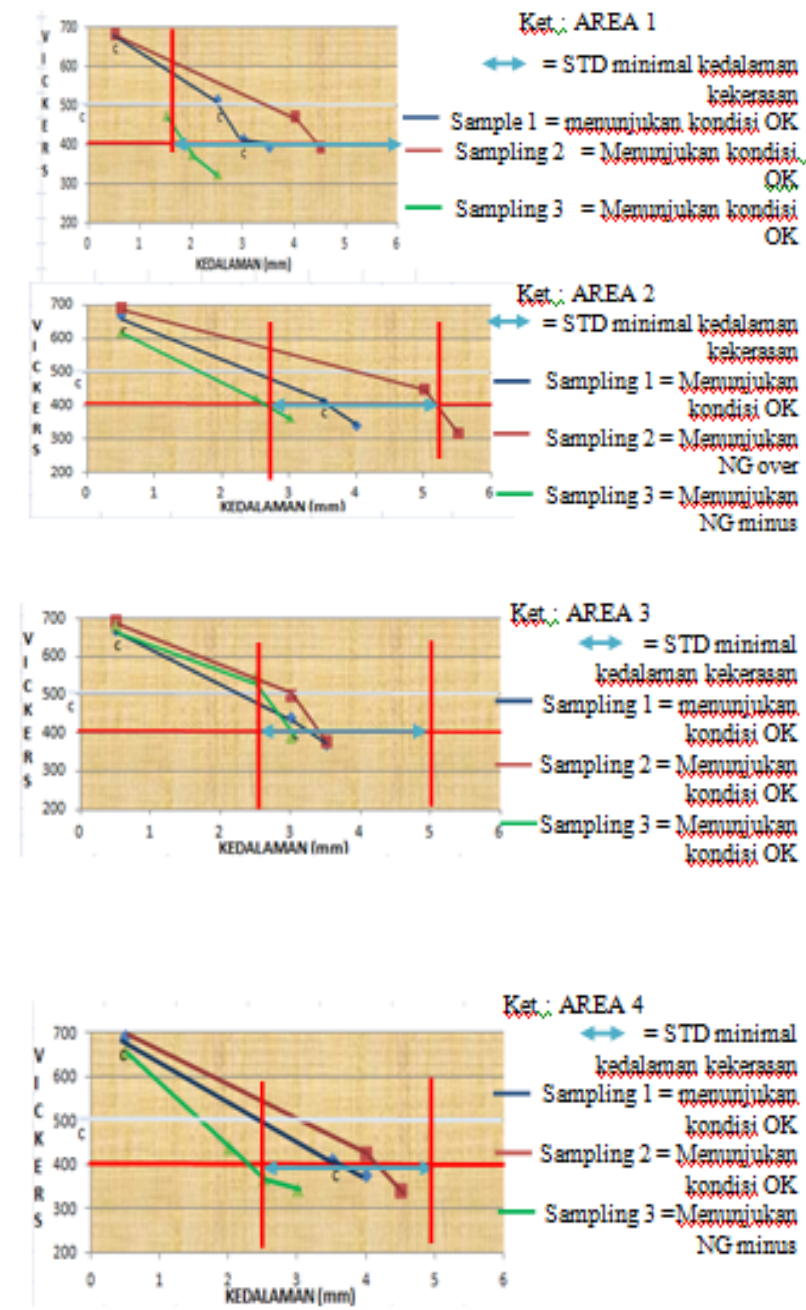

D Gambar 19. Diagram Perbandingan Kedalaman Penetrasi dari 3 Contoh

Dari gambar 19 diatas dapat disimpulkan bahwa area 1 \& 3 walau dengan parameter dan kondisi setting yang berbeda masih dalam kondisi hasil ok untuk tuntutan kualitas kedalaman penetrasi kekerasan efektif. Jadi parameter-parameter pada area $1 \& 3$ dapat dijadikan referensi toleransi setting parameter awal. Berikut adalah toleransi parameter area $1 \& 3$ dengan dasar perbandingan adalah hasil test cutting kedalaman penetrasi efektif. Berikut analisa perbandingan parameter aktual dan posisi area.
Parameter prosers area 1

\begin{tabular}{|c|c|c|c|}
\hline POS (nm) & $\begin{array}{c}\text { Timer (sec) } \\
\text { STD }\end{array}$ & $\begin{array}{c}\text { Speed }(\mathbf{m m} / \mathrm{s}) \\
\text { STD }\end{array}$ & $\begin{array}{c}\text { Power }(\mathrm{KW}) \\
\text { STD }\end{array}$ \\
\hline $867,6-1026,3$ & 0 & 0 & 0 \\
\hline $867,6-1026,3$ & 1,5 & 0 & $128-164$ \\
\hline
\end{tabular}

\begin{tabular}{|l|c|c|c|c|}
\hline \multicolumn{1}{|c|}{ PRESS \& TEMP } & SAMPLE & SAMPLE & SAMPLE & STANDAR \\
& $\mathbf{1}$ & $\mathbf{2}$ & $\mathbf{3}$ & \\
\hline Q.W PRESSURE $\left(\mathrm{Kg} / \mathrm{cm}^{21}\right.$ & 6 & 5 & 5 & $\geq 6$ \\
\hline Q.W TEMP $\left({ }^{\circ} \mathrm{C}\right)$ & 26 & 32 & - & $\mathbf{2 6}$ \\
\hline
\end{tabular}

\begin{tabular}{|c|c|}
\hline CW TEMP(\%) & $25 \sim 38$ \\
\hline Cycle Time (second) & $177-178$ \\
\hline Quenching flow \pm 20 (1/min) & $80-100$ \\
\hline Concentration(\%) & $3-4$ \\
\hline Coil Gap (mI) & 1.5 \\
\hline
\end{tabular}

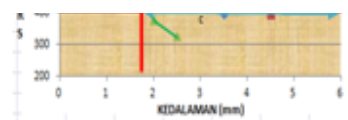

Gambar 20. Grafik Hasil Kedalaman Penetrasi Area 1

Parameter kondisi area 2 material poros axle shaft jenis material S-43, yang hasil test cutting kedalaman penetrasi efektif nya menunjukan hasil ok hanya sampling 1, sehingga parameter kondisi area 2 yang dapat distandarkan sesuai dasar parameter hanya kondisi sampling 1 juga, yaitu:

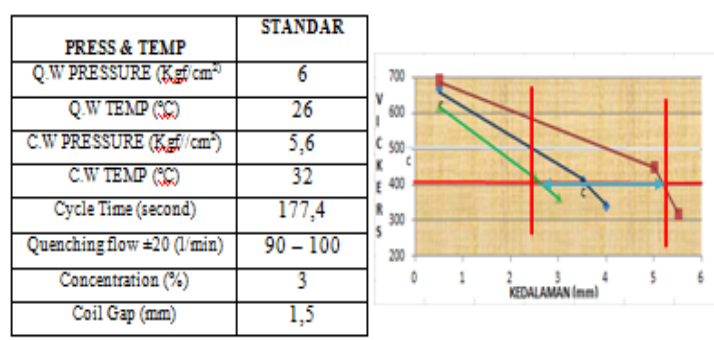

\section{$\underline{\text { Parameter prosess area } 3}$}

\begin{tabular}{|c|c|c|c|}
\hline POS (mm) & $\begin{array}{c}\text { Timer }(\mathrm{sec}) \\
\text { STD }\end{array}$ & $\begin{array}{c}\text { Speed }(\mathrm{mm} / \mathrm{s}) \\
\text { STD }\end{array}$ & $\begin{array}{c}\text { Power (KT) } \\
\text { STD }\end{array}$ \\
\hline $809-931$ & 0 & $5,7-5,8$ & $110-117$ \\
\hline
\end{tabular}

Gambar 21. Grafik Hasil Kedalaman Penetrasi Area 2

Parameter kondisi area 3 pada material poros axle shaft jenis material s-43 ini, dapat dilihat sampling 1 sampai sampling 3 menunjukan hasil test cutting kedalaman penetrasi efektif ok sesuai tuntutan standar yang diminta. Sehingga parameter kondisi 1 dapat distandarkan sesuai standar parameter sampling 1, yaitu 


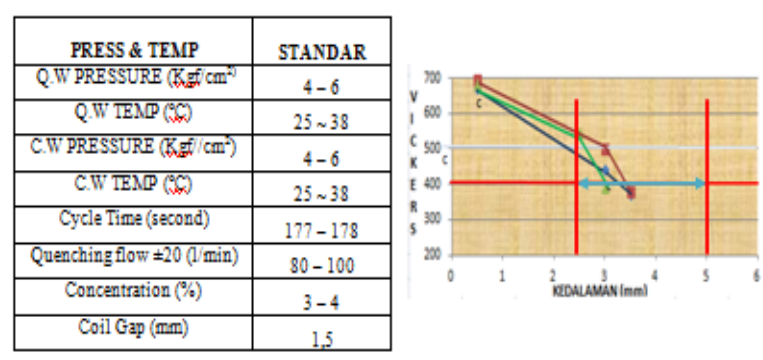

Gambar 22. Grafik Hasil Kedalaman Penetrasi Area 3

Parameter prosessarea 4
\begin{tabular}{|c|c|c|c|}
\hline POS (mm) & $\begin{array}{c}\text { Timer (sec) } \\
\text { STD }\end{array}$ & $\begin{array}{c}\text { Speed (mm/s) } \\
\text { STD }\end{array}$ & $\begin{array}{c}\text { Power (KW) } \\
\text { STD }\end{array}$ \\
\hline $209-293$ & 0 & $6,1-8,1$ & $110-117$ \\
\hline $100-275$ & 0 & $24,9-28,2$ & 0 \\
\hline $100-253$ & $8-15$ & 0 & 0 \\
\hline
\end{tabular}

Pada proses area 4, sampling yang ok adalah sampling 1 \& sampling 2. Sehingga parameter kondisi yang dapat dijadikan referensi penyetelan adalah dari sampling 1 \& sampling 2 yang samasama menunjukan hasil test cutting kedalaman penetrasi efektif ok sesuai tuntutan standar yang diminta

\begin{tabular}{|c|c|}
\hline PRESS \& TEMP & STANDAR \\
\hline Q.W PRESSURE (Kझf $\mathrm{cm}^{2}$ & $5-6$ \\
\hline Q.W TEMP (MC) & $26 \sim 32$ \\
\hline CW PRESSURE (Kפ $\left./ \mathrm{cm}^{2}\right)$ & $0,09-5,6$ \\
\hline CW TEMP (CM) & 32 \\
\hline Cycle Time (second) & $130,8-177,4$ \\
\hline Quenching flow $\pm 20(1 / \mathrm{min})$ & $80-100$ \\
\hline Concentration (\%) & $2-3$ \\
\hline Coil Gap (nn) & 1,5 \\
\hline
\end{tabular}

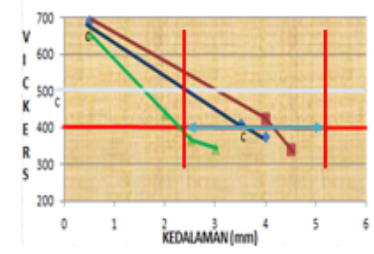

Gambar 23. Grafik Hasil Kedalaman Penetrasi Area 4

\section{Analisa Parameter Proses Berdasarkan Area Proses}

Berdasarkan parameter proses di 4 area (area 1 - area 4) pada material poros axle shaft dari 3 sampling diatas maka dapat ditarik kesimpulan sementara untuk parameter proses area induksi hardening mc 12-9.b untuk material poros axle shaft s-43 adalah sebagai berikut ini :

\begin{tabular}{|c|c|c|c|}
\hline POS (mm) & $\begin{array}{c}\text { Timer (sec) } \\
\text { STD }\end{array}$ & $\begin{array}{c}\text { Speed (mm/s) } \\
\text { STD }\end{array}$ & $\begin{array}{c}\text { Power (KW) } \\
\text { STD }\end{array}$ \\
\hline $867,6-1026,3$ & 0 & 0 & 0 \\
\hline $867,6-1026,3$ & 1,5 & 0 & $128-164$ \\
\hline $856-1016$ & 0 & $2,5-2,6$ & 125 \\
\hline $809-931$ & 0 & $5,7-5,8$ & $110-117$ \\
\hline $209-293$ & 0 & $6,1-8,1$ & $110-117$ \\
\hline $100-275$ & 0 & $24,9-28,2$ & 0 \\
\hline $100-253$ & $8-15$ & 0 & 0 \\
\hline
\end{tabular}

каıаu aиpernatıkan darl parameter proses area diatas terdapat angka toleransi yang cukup berbeda. Hal ini dapat kita pertimbangkan dari parameter kondisi yang berbeda. Berdasarkan hasil test cutting kedalaman penetrasi kekerasan efektif, sampling yang hasilnya dapat diterima sesuai tuntutan standar kualitas pada 4 area posisi poros axle shaft adalah sample 1 yang diambil tanggal 31 - 05 - 2013. Jadi, berdasarkan data dan hasil test cutting maka parameter sample 1 dijadikan referensi dasar penyetelan parameter kondisi.

Berikut adalah parameter yang dijadikan kesimpulan sementara pada parameter kondisi yang dijadikan standar sementara dalam melihat parameter kondisi mesin

Tabel 10. Grafik Hasil Kedalaman Penetrasi Area 1

\begin{tabular}{|l|c|c|c|c|}
\hline \multicolumn{1}{|c|}{ PRESS \& TEMP } & SAMPLE & SAMPLE & SAMPLE & STANDAR \\
& $\mathbf{2}$ & $\mathbf{2}$ & $\mathbf{3}$ & \\
\hline Q.W PRESSURE ( $\left(\mathrm{k}\right.$ f $\left./ \mathrm{cm}^{2}\right)$ & 6 & 5 & 5 & $\geq 6$ \\
\hline Q.W TEMP ("C) & 26 & 32 & - & 26 \\
\hline
\end{tabular}

\begin{tabular}{|l|c|c|c|c|}
\hline C.W PRESSURE $\left(\mathrm{Kg}_{\mathrm{F}} / \mathrm{cm}^{2}\right)$ & 5,6 & 0,09 & 4,6 & $\geq \mathbf{5 , 6}$ \\
\hline C.W TEMP ("C) & 32 & 32 & 34 & $\leq \mathbf{3 2}$ \\
\hline Cycle Time (second) & 177,4 & 130.8 & 173,3 & $\geq \mathbf{1 7 7 , 4}$ \\
\hline Quenching flow $\pm 20(\mathrm{l} / \mathrm{min})$ & $90-100$ & 80 & $85-100$ & $\mathbf{9 0 - 1 0 0}$ \\
\hline Concentration (\%) & 3 & 2,0 & 3,5 & $\mathbf{3}$ \\
\hline Coil Gap (mm) & 1,5 & 1,5 & 1,5 & $\mathbf{1 , 5}$ \\
\hline & OK & NG Over & NG Minus & \\
\hline
\end{tabular}

Darl standar sementara pada tabel $1 U$ diatas, hasilnya standar parameter kondisi nya kita uji kembali dengan mengambil data initial sample 4 \& 5 pada tanggal 5 \& 10 juli 2013. Hal ini dimaksudkan untuk menguji korelasi kebenarannya dari data-data parameter acuan di kesimpulan sementara diatas.

Berdasarkan data-data diatas, baik parameter posisi proses ataupun parameter kondisi. Dapat kita tarik kesimpulan sementara referensi penyetelan parameter proses induksi hardening material poros axle shaft jenis s-43 pada mesin induksi hardening 1080 kora neturent tahun 2010 dengan kode mesin 12-9.b adalah sebagai berikut

Tabel 11. Pengujian Kesimpulan Parameter Kondisi Sementara.

\begin{tabular}{|c|c|c|c|c|}
\hline PRESS \& TEMP & STANDAR & $\begin{array}{c}\text { SAMPLE } \\
4\end{array}$ & $\begin{array}{l}\text { SAMPLE } \\
\mathbf{5}\end{array}$ & $\begin{array}{l}\text { KORE } \\
\text { LASI }\end{array}$ \\
\hline Q.W PRESSURE $\left(\mathrm{K} f / \mathrm{cm}^{2}\right)$ & $\geq 6$ & 6,2 & 5 & $\mathrm{X}$ \\
\hline Q.W TEMP ( $\left.{ }^{\circ} \mathrm{C}\right)$ & 26 & & & $\mathrm{X}$ \\
\hline $\begin{array}{ll}\text { C.W } & \text { PRESSURE } \\
\left(\mathrm{K} / \mathrm{f} / \mathrm{cm}^{2}\right)\end{array}$ & $\geq 5,6$ & 5,2 & 3 & $\mathrm{x}$ \\
\hline C.W TEMP $\left({ }^{\circ} \mathrm{C}\right)$ & $\leq 32$ & 34 & 30 & $\mathrm{X}$ \\
\hline Cycle Time (second) & $\geq 177,4$ & 149,4 & 182,7 & $\mathrm{x}$ \\
\hline Quenching flow $\pm 20(\mathrm{l} / \mathrm{min})$ & $90-100$ & $90-100$ & $90-95$ & $\mathrm{OK}$ \\
\hline Concentration (\%) & 3 & 3 & 3 & $\mathrm{OK}$ \\
\hline Coil Gap (mm) & 1,5 & 1,5 & 1,5 & $\mathrm{OK}$ \\
\hline $\begin{array}{l}\text { JUDGEMENT CUTTING } \\
\text { TEST }\end{array}$ & & OK & $\mathrm{OK}$ & \\
\hline
\end{tabular}

Dari data parameter kondisi pada tabel 11 dapat kita simpulkan parameter kondisi yang berkorelasi langsung dengan kedalaman penetrasi kekerasan efektif material poros axle shaft ini adalah "parameter quenching flow dengan nilainya harus diangka 90-100 l/min, concentration aqua quench harus 3\%, \& gap coil dengan material harus 1,5 mm”.

Berdasarkan parameter kondisi sample standar yang ada di kesimpulan sementara di atas, dan datadata yang ada di sample 1 sampai dengan sample 3 . 
Untuk menghasilkan standar kualitas yang sesuai, parameter kondisi sangat berpengaruh terhadap parameter proses area. Apabila terdapat perbedaan pada parameter kondisi karena ada penurunan performance mesin, maka penyetelan parameter proses area pasti akan berubah juga untuk menjaga hasil effective depth hardness (kedalaman penetrasi kekerasan efektif) yang sama juga. Hal ini dapat kita pahami dengan melihat perbandingan sampling 4 dan sampling 5 yang memiliki hasil initial test cutting oke tetapi memiliki penyetelan parameter proses area yang berbeda. Seperti yang ditunjukan pada tabel perbandingan parameter proses area di tabel 12 dibawah ini.

Tabel 12. Perbandingan Darameter proses

\begin{tabular}{|c|c|c|c|c|c|c|c|c|c|}
\hline \multirow{2}{*}{ POS (mm) } & \multicolumn{4}{|c|}{ Timer (sec) } & \multicolumn{3}{|c|}{$\begin{array}{c}\text { Speed (mm/s) } \\
\text { STD }\end{array}$} & \multicolumn{3}{c|}{$\begin{array}{c}\text { Power (KW) } \\
\text { STD }\end{array}$} \\
\cline { 2 - 9 } & 4 & $\mathbf{5}$ & STD & 4 & $\mathbf{5}$ & STD & 4 & $\mathbf{5}$ & STD \\
\hline $867,6-1026,3$ & 0 & 0 & 0 & 0 & 0 & 0 & 0 & 0 & 0 \\
\hline $867,6-1026,3$ & 1,8 & 1,8 & 1,5 & 0 & 0 & 0 & 129 & 125 & $128-164$ \\
\hline $856-1016$ & 0 & 0 & 0 & 2,9 & 2,5 & $2,5-2,6$ & 127 & 117 & 125 \\
\hline $809-931$ & 0 & 0 & 0 & 5,6 & 5,6 & $5,7-5,8$ & 119 & 114 & $110-117$ \\
\hline $209-293$ & 0 & 0 & 0 & 6,4 & 6,4 & $6,1-8,1$ & 117 & 112 & $110-117$ \\
\hline $100-275$ & 0 & 0 & 0 & 24,9 & 24,9 & $\begin{array}{c}24,9- \\
28,2\end{array}$ & 0 & 0 & 0 \\
\hline $100-253$ & 15 & 15 & 15 & 0 & 0 & 0 & 0 & 0 & 0 \\
\hline
\end{tabular}

Ket:

setting parameter prosess area yang tidak sesugai range toleransi

\section{KESIMPULAN}

Dari hasil pengujian dan analisis datanya berdasarkan metode-metode pada tinjauan pustaka diperoleh kesimpulan sebagai berikut:

1. Hasil kedalaman penetrasi dapat stabil atau berada di grafik interpolasi min $400 \mathrm{hv}$, apabila penunjukan parameter kondisi aktual keluaran mesin stabil sesuai standard parameter yang dibahas di diagram 5.1, yaitu quenching flow (lt/menit), concentration aqua quench (\%), \& coil gap dengan material (mm)

2. Parameter kondisi yang berkorelasi langsung dengan kedalaman penetrasi kekerasan efektif material poros axle shaft s-43 model d-01n harus konstan dan stabil pada nilai dibawah ini antara lain parameter quenching flow dengan nilainya harus diangka 90-100 l/min, concentration aqua quench harus $3 \%$, \& gap coil dengan material harus $1,5 \mathrm{~mm}$ ".

3. Untuk mendapatkan nilai effective depth hardness ok / sesuai tuntutan standar, dengan kondisi parameter kondisi yang berubah terkecuali quenching flow, concentration, dan coil gap dapat kita setting nilai input pada program penyetelan parameter proses area.
Nilai effective depth hardness dapat kita cari dengan tepat besarannya dengan rumus interpolasi.

\section{DAFTAR PUSTAKA}

Metallic Materials Vickers Hardness Test part 1, iso second ed., 1997-11-15, Swizerland ISO 6507-1:1997

Bradbury, "Dasar Metalurgi Untuk Rekasasawan” PT. Gramedia Pustaka Utama. 1997

Djaprie, Sriati. “Teknologi Mekanik” jilid 1 Erlangga, Jakarta. 1992

Avner, s.h., "Introduction To Physical Metallurgy", mc. Graw-hill, new york, 1964.

www.wikipedia.com/2013/02/heat treatment.html

Http:www.egiskren.blogspot.com /2013/02/klasifikasi 